\title{
INDEXACÃO DE XILOGRAVURAS À LUZ DA SEMÂNTICA DISCURSIVA
}

\author{
INDEXATION OF XYLOGRAVURES IN THE LIGHT OF DISCURSIVE \\ SEMANTICS
}

Raimunda Fernanda dos Santos ${ }^{1}$

\begin{abstract}
RESUMO
Estuda a indexação de xilogravuras cujas imagens expressivas representam narrativas da memória e da cultura popular, evocando em seus leitores percepções e sensações plurais. Tem como objetivo geral apresentar uma proposta de metodologia para a indexação de imagens, em especial xilogravuras, considerando o arcabouço teórico-metodológico da Semântica Discursiva. Utiliza metodologia de caráter descritivo e exploratório pautada na abordagem qualitativa, com universo que compreende os folhetos de cordel cujas xilogravuras e versos foram produzidos pelo poeta e xilógrafo Marcelo Soares. Busca subsídio teórico-metodológico na discursivização semântica, privilegiando os processos de figurativização e tematização, no intuito de contribuir para a produção significativa de metadados semânticos na indexação de imagens. Considera que a análise de imagens como as xilogravuras deve estar pautada, primeiramente, na narrativa visual e na articulação semântica da mesma com o conteúdo das fontes adicionais relacionadas a esses recursos (como o título, legendas, versos do folheto e tags atribuídas pelos usuários em um dado sistema), contemplando os procedimentos de figurativização e tematização da Semântica Discursiva. Constata que a Semântica Discursiva é ferramenta contribuinte para que os profissionais indexadores tenham certeza de que estão muito mais próximos dos temas retratados nas xilogravuras. Palavras-chave: Indexação de imagens. Xilogravuras de cordel. Semântica Discursiva. Informação imagética.
\end{abstract}

\begin{abstract}
Studies an indexing of woodcuts whose expressed images represent narratives of memory and popular culture, evoking in his readers plural perceptions and sensations. General objective is to present a proposed methodology for indexing images, especially woodcuts, considering the theoretical-methodological framework of Discursive Semantics. Use the descriptive and exploratory methodology based on the qualitative approach, with the universe comprising the cord leaflets whose woodcuts and verses were used by the poet and woodcutter Marcelo Soares. Seeks theoretical-methodological support in semantic discourse, privileging the processes of figuration and thematization, with no intention of contributing to the significant production of semantic metadata in image indexing. Consider that an analysis of images such as woodcuts must be based on, use, visual narrative and semantic articulation of the same with the content of sources related to these resources (such as title, captions, package verses and tags assigned by users in a given system), contemplating the figurative and thematic procedures of Discursive Semantics. Finds that Discursive Semantics is a tool that helps index professionals to be sure that they are much closer to the themes portrayed in the woodcuts.
\end{abstract}

Keywords: Indexing images. Woodcuts of twine. Discursive Semantics. Image information.

Artigo submetido em 24/04/2020 e aceito para publicação em 03/05/2020

1 Professora na Universidade Federal do Rio de Janeiro, Brasil. ORCID: https://orcid.org/0000-0002-7750-3269. E-mail: fernanda@facc.ufrj.br 


\section{INTRODUÇÃo}

A indexação consiste em uma atividade integrante da representação temática da informação, que visa descrever os conteúdos dos itens informacionais por meio de termos, também denominados de descritores, que se configuram como, ou se propõem a ser, pontos de acesso para fins de disponibilização das informações pertinentes às necessidades dos usuários. Assim, todas as fases do processo de indexação, como análise conceitual e representação, fazem parte das técnicas realizadas pelos profissionais da informação e devem estar associadas a uma política de indexação, sendo influenciadas por fatores linguísticos, cognitivos, lógicos, ideológicos, contextuais e culturais, simultaneamente.

Os fatores supracitados podem adquirir um grau de complexidade ainda maior quando aplicados ao tratamento temático de imagens, uma vez que o conteúdo dos recursos imagéticos não é textual. Esses recursos podem emitir conceitos concretos e abstratos e os seus significados podem ser influenciados pelo contexto, uso pretendido e usuário.

Por esse motivo, as imagens podem ser visualizadas, representadas e recuperadas de maneiras diferentes por diversos usuários, podendo haver divergências entre as percepções dos usuários e as descrições realizadas pelo profissional da informação em bancos de imagens ou sistemas de recuperação da informação.

Diante disso, um dos desafios da indexação de imagens é estabelecer, de maneira confiável e consistente, termos considerados representativos para descrever o conteúdo desses recursos complexos e altamente subjetivos.

Nesse limiar, as imagens, em especial as xilogravuras, objetos desta pesquisa, apresentam informações que precisam ser analisadas e tratadas para fins de sua recuperação, acesso e uso. Isso se deve ao fato de que 0 artista encontra no recurso imagético uma maneira de transmitir suas manifestações artísticas, tornando-o uma fonte inesgotável da cultura popular, procurando representar bichos, demônios e todas as demais figuras reais ou irreais que a sua criativa imaginação vislumbra (CARVALHO, 2014).

Merece ainda uma atenção especial a indexação das xilogravuras cujas ilustrações expressivas trazem consigo a originalidade dos xilógrafos, inspiradas na poesia e apresentadas em capas de folhetos de cordel, evocando em seus leitores as diversas acepções e memórias. Essas imagens representam a narrativa de cordel e são imprescindíveis na construção histórica da cultura popular e do modo de 
pensar de um povo. Nessa arte, o conteúdo da escrita é representado através da imagem, ou seja, o pensamento criador do artista (xilógrafo) é inspirado na poesia para a representação do homem popular sob a perspectiva de sua história, seus dilemas, leitura de mundo, etc.

0 artista que ilustra os seus próprios folhetos e narrativas no cordel é considerado poeta e xilógrafo. Assim, o pensamento criador desse artista para a construção da arte na xilogravura é inspirado em seu próprio texto ou poesia. Entendendo isso, observa-se que a imagem se configura como um registro do fragmento de um mundo visível. 0 referente, objeto enfocado na xilogravura, é constituído pelo olhar ou enquadramento do xilógrafo e evidencia um foco, cujas análises efetuadas por diferentes pessoas podem ser alvo de interpretações plurais.

A representação simbólica relacionada à imagem e que não se encontra visível na mesma, também suscita diversas interpretações inerentes à capacidade imaginativa dos sujeitos. Esses elementos se tornam mais complexos no que diz respeito às práticas de identificação do conteúdo nesses recursos.

Para tanto, surgem os seguintes questionamentos: Como identificar e selecionar termos representativos para indexar recursos imagéticos complexos e subjetivos como as xilogravuras? Quais as regras podem ser contempladas para que essas práticas contribuam para a produção significativa de metadados semânticos?

Visando responder essas indagações, foram elencados alguns objetivos, os quais norteiam os procedimentos metodológicos e as análises qualitativas deste estudo.

Assim, o objetivo geral deste artigo consiste em apresentar uma proposta de metodologia para a indexação de imagens, em especial de xilogravuras de cordel, considerando o arcabouço teóricometodológico da Semântica Discursiva. Tendo como norte a pesquisa mais ampla, neste artigo foram empreendidos esforços para subsidiar as práticas de indexação de xilogravuras com base na Semântica Discursiva, visando compilar parte dos resultados da pesquisa doutoral da autora. Na Tese é trabalhada a dimensão metodológica cujo diferencial está ancorado na preocupação da identificação de procedimentos eficazes para a representação dessa tipologia de recursos imagéticos, utilizando a Semântica Discursiva como arcabouço teórico-metodológico e as potencialidades da Folksonomia.

Sobre esse prisma, considera-se que a Semântica Discursiva, mediante os procedimentos de tematização e figurativização, consiste em uma ferramenta contribuinte para a análise e indexação de imagens. Portanto, acredita-se que a metodologia proposta pode contribuir para a produção significativa de metadados semânticos para indexar recursos imagéticos, em especial xilogravuras. A proposição 
em questão não visa engessar a criatividade do profissional da informação e/ou limitar a participação do(s) usuário(s) e sim tem o intuito de orientar no que concerne às práticas de extração do conteúdo de xilogravuras, trazendo como diferencial a redução do nível de subjetividade - tornando a indexação mais próxima possível de atender os parâmetros conceituais desses recursos imagéticos. Além disso, as diretrizes propostas podem servir de referência para o desenvolvimento de atividades de indexação de imagens, podendo ser adaptadas ou aperfeiçoadas em diversos contextos.

A importância do estudo decorre, em âmbito geral, da ausência de procedimentos metodológicos para a indexação de xilogravuras com vistas à identificação de assuntos e, consequentemente, da sua recuperação. São encontrados na literatura científica métodos e técnicas associados à análise de documentos fotográficos, não contemplando as especificidades das xilogravuras.

Adicionalmente, ainda não foram identificadas investigações científicas que propõem metodologias e diretrizes que utilizam as potencialidades da Semântica Discursiva para a indexação de imagens e que trazem, ao mesmo tempo, a valorização da memória coletiva e da cultura popular por meio de estudos sobre xilogravuras de cordel na Ciência da Informação.

Sob esse prisma, acredita-se que esta investigação traz significativas contribuições para essa área do conhecimento, dada a carência de estudos que contemplem, de maneira interdisciplinar, questões teórico-metodológicas sobre indexação de imagens como xilogravuras, estabelecendo interfaces entre Semântica Discursiva e representação da informação. Portanto, observa-se que a Ciência da Informação não pode se isentar dos estudos que visam o desenvolvimento da competência dos profissionais da informação, pesquisadores e usuários que lidam com as práticas de representação temática de recursos imagéticos.

\section{IMAGENS: abordagens e percursos na representação da informação}

A produção de imagens é crescente na sociedade e com ela surgem variadas demandas para 0 armazenamento, organização, recuperação, acesso e uso. Esses recursos estão ligados ao fenômeno da linguagem, dessa forma não é possível estudá-las sem considerar a representação. As imagens suscitam percepções e sensações diferenciadas, portanto precisam ser analisadas, ressignificadas, representadas e organizadas em função das suas especificidades e das necessidades informacionais dos usuários.

Joly (2012, p. 38) destaca que imagens são "algo que se assemelha a outra coisa", o que faz que com se encaixem nas categorias das representações. Se ela aparece é porque não é a coisa 
propriamente dita, portanto, a sua função é evocar através do processo de semelhança. Nesse entendimento, a significação de uma mensagem visual é construída pela interação de diferentes tipos de signos (plásticos, icônicos, linguísticos) cuja interpretação está atrelada à cognição, ao saber cultural e sociocultural do leitor ou usuário.

No que concerne às pesquisas e enfoques sobre análise de imagens na área de Ciência da Informação, contata-se que esses estudos predominam no contexto dos documentos fotográficos. Como modalidade de imagens, nesta seção são abordados aspectos concernentes às imagens visuais estáticas ou fixas cujos suportes são analógicos ou digitais.

Como diz Barthes (1990, p. 32): "toda imagem é polissêmica e pressupõe subjacentes os seus significantes, uma cadeia flutuante de significados". Seguindo essa linha de raciocínio, é possível inferir que as imagens possuem o caráter polissêmico e heterogêneo, pois veiculam um grande número de informações e são compartilhadas socialmente, suscitando percepções e sensações plurais.

Essa assertiva coaduna com as dimensões cultural e ética da representação da informação. Muitas imagens não são reconhecidas, assimiladas, interpretadas por profissionais e/ou indivíduos que fazem parte de determinadas culturas pelo fato deles não possuírem conhecimentos adequados para entendê-las, uma vez que os sujeitos atribuem sentido às coisas pela maneira como as utilizam ou as integram e associam em suas práticas cotidianas.

Assim, as imagens são interpretadas e analisadas de acordo com a leitura de mundo, a memória e a cognição dos seus leitores. Com base nas ideias de Umberto Eco, Joly (2002) ressalta que as imagens carregam consigo um conjunto de informações que podem ser identificadas, analisadas, interpretadas, (res)significadas na perspectiva de três elementos: o autor ou criador (o que ele quis dizer), a obra (o que a obra diz) e o leitor ou receptor (o que ele privilegiou na mensagem).

Sob esse viés, considerando que as imagens suscitam percepções e sensações plurais, Hall (1997, p. 27) infere que não há uma resposta única ou verdadeira acerca de "o que uma imagem quer dizer" ou ainda "o que determinado anúncio significa". Portanto, as práticas de análise e interpretação de imagens não devem estar pautadas no debate entre 0 certo e 0 errado, mas sim entre as possibilidades plausíveis de representação a partir de observações contextuais.

No âmbito da Ciência da Informação, a atividade de analisar recursos imagéticos está pautada em uma operação denominada análise documentária de imagens, a qual contribui para a representação e organização da informação imagética com vistas ao acesso e uso desses objetos informacionais pelos usuários, aspecto a ser discutido na próxima subseção. 


\subsection{Análise documentária de imagens}

A análise documentária de imagens diz respeito a uma operação que agrega um conjunto de práticas que viabilizam a compreensão, descrição, representação e organização dos conteúdos de itens informacionais através do uso de técnicas e procedimentos provenientes dos estudos e investigações da área de Ciência da Informação, objetivando a recuperação, o acesso e 0 uso da informação independentemente do seu suporte.

Assim como os textos, os recursos imagéticos, a exemplo das pinturas, das xilogravuras e das fotografias, etc. também são "lidos" e analisados. Entretanto, a operação de análise adquire um grau de complexidade maior quando aplicada ao contexto das imagens, pois elas possuem característica heterogênica e polissêmica diante da sua capacidade de suscitar várias percepções.

De acordo com Manini (2002) a análise documentária de imagens, assim como a de textos, iniciase com a leitura do documento. Essa atividade requer do profissional da informação conhecimento prévio sobre o conteúdo do recurso imagético ou do conjunto maior de que faz parte. Porém, isso não deve se configurar como fator condicionante para a execução dessa atividade, uma vez que 0 indexador pode extrair informações adicionais acerca do recurso em outras fontes de informação, dando importância também aos interesses do usuário do banco de imagens e às linguagens documentárias existentes.

Os aspectos associados à mente humana são complexos e interferem, por exemplo, na maneira como um sujeito realiza a análise de uma imagem, o que exige a necessidade de métodos específicos para a indexação desse recurso, tendo em vista a sua capacidade de gerar diversas significações. Isso se deve ao fato de que 0 indexador, por meio do processamento de dados sensoriais, pode destacar os significados da imagem que mais Ihe interessam, no momento da indexação, podendo não necessariamente satisfazer as necessidades dos usuários.

Sob esse viés, Joly (2012) preconiza que a atividade de análise de imagens deve ser baseada em metodologias adequadas e itens informacionais pré-estabelecidos, bem como no estabelecimento de pontos de referência para a sua análise pautados no usuário e nas suas necessidades de informação.

Portanto, metodologias empregadas na indexação de recursos textuais não devem ser mecanicamente aplicadas no universo da indexação de imagens. No intuito de discutir essas questões e apresentar contribuições voltadas especificamente para a análise de imagens, as produções científicas da área de Ciência da Informação estão, em sua maioria, direcionadas para documentos fotográficos e se referem ao trabalho de Erwin Panofsky (1977), crítico e historiador de arte que criou a teoria da 
análise iconológica, ${ }^{2}$ cujo método busca compreender uma obra através de três níveis de análise, são eles: pré-iconográfico, iconográfico e iconológico. Essa teoria serviu como base para a construção de diferentes metodologias de representação de fotografias apresentadas por diversos autores, dentre eles: Shatford (1986), Smit (1996), Manini (2002), Rodrigues (2007), Pato (2015).

Essas metodologias propostas salientam que a indexação deve ser realizada com base no que as fotografias apresentam, ou seja, os referentes (coisas e objetos do mundo visível). Para tanto, os indexadores necessitam reconhecê-los nas imagens e nomeá-los para fins de representação.

\section{XILOGRAVURAS: imagens que retratam a realidade e 0 imaginário popular}

A xilogravura consiste em uma arte antiga talhada em suporte de madeira, denominado como matriz, e foi utilizada inicialmente para copiar e reproduzir outras obras de arte (desenhos, pinturas, etc.) no intuito de torná-las conhecidas (LICARIÃO, [199-?]). De acordo com Souza (1980 apud MACHADO; ALBUQUERQUE, 2016, p. 857), para a constituição dessa arte 0 xilógrafo recorta as partes da madeira até formar a estampa que pretende através de desenhos e/ou textos nas partes deixadas em relevo na matriz. Sendo assim, para a realização da sua impressão aplica-se a tinta no suporte em madeira utilizando a prensa para a transferência da imagem e/ou do texto para outro suporte.

Para Carvalho (2014), xilogravura é, portanto, o resultado do corte em madeira de tipos diferentes, dentre as quais: casca de cajá, mogno, pinho, pau-amarelo, imburana. Por isso, a seleção do tipo de madeira depende da preferência de cada xilógrafo. Quanto aos instrumentos de incisão, a goiva, o formão, o estilete, a faquinha e o buril são os principais instrumentos de trabalho desses artistas.

Com o avanço tecnológico foram surgindo algumas soluções alternativas ao emprego da madeira, sem que isso afetasse a expressão criadora da imagem. "As variações de material e de técnica fazem crer que a xilogravura se atualiza, sem, contudo, romper com os procedimentos mais arraigados dessa manifestação da cultura popular" (CARVALHO, 2014, p. 190).

Em linhas gerais, verifica-se a relação intrínseca das xilogravuras com a cultura de cada povo. Essas imagens antecederam as fotografias e no decorrer da história da humanidade têm se configurado fontes de informação para letrados e iletrados, expressando pontos de vistas críticos que suscitam reflexões e leituras mentalizadas em contextos e temáticas plurais.

2 A primeira etapa desse método é a leitura iconográfica, que diz respeito à análise descritiva, e a segunda etapa é a leitura iconológica diretamente associada à interpretação da obra (PANOFSKY, 2007). 
Outro aspecto importante a ser considerado nas xilogravuras é o fato de que elas expressam elementos reais e imaginários. Os elementos reais representados nas xilogravuras estão associados aos aspectos provenientes de uma determinada realidade, contexto ou acontecimento, interpretados pelos xilógrafos. Em nítido contraste, os elementos imaginários representados espontaneamente nessas imagens são provenientes das invenções fantasiadas na cognição desses artistas ou baseados em estórias e lendas contadas em uma determinada região. Nesse último caso, a realidade se configura como um produto do imaginário.

A representação de uma arte em outra arte, por exemplo a xilogravura na literatura de cordel, se constitui como uma maneira de analisar as relações das diferentes artes entre si e 0 aspecto representativo e interpretativo que elas incitam. De acordo com Carvalho (2014), embora não possam ser consideradas irmãs gêmeas dos folhetos poéticos, as xilogravuras -principalmente aquelas produzidas na região nordeste do Brasil- se identifica de tal modo que passou a competir com as formas tradicionais de ilustração de suas capas.

De acordo com Aguiar et al. (2008, p. 2), a "literatura de cordel é uma poesia narrativa e popular escrita em versos, rimada e metrificada". Trata-se de um material informacional que reflete a cultura e o modo de pensar de um povo, ou seja, possui um caráter social. 0 cordel tem sido reconhecido como "artefato informacional e memorialístico" e como "um gênero literário de peso na memória da tradição" (ALBUQUERQUE et al., 2016, p. 14), atravessando o período da ditadura militar no Brasil e se inserindo no contexto escolar e acadêmico como instrumento de pesquisas científicas, retratando o rico imaginário popular.

Na publicação do Diário Oficial da União de 20 de agosto de 2018, junto à notícia de que 0 cordel foi registrado pelo IPHAN como patrimônio cultural do Brasil, foi apresentada também a relação das xilogravuras com esses folhetos.

As capas [dos folhetos de cordel] merecem um destaque à parte em função da imagem que ilustra o folheto. Não se trata de uma mera ilustração do texto, mas tem função mnemônica, condensando a trama da narrativa, e função metafórica, multiplicando sentidos e significados que abarcam a observação do cotidiano e da vida social. Dentre todas as técnicas imagéticas já empregadas, a arte da xilogravura acabou conferindo uma identidade visual ao folheto de cordel (BRASIL, 2018, p.12).

Relacionados a essa arte existem dois tipos de xilógrafos: 1) 0 artista que apenas ilustra os folhetos escritos por outros, ou seja, são apenas xilógrafos; 2) 0 artista que ilustra seus próprios folhetos, isto é, são xilógrafos e poetas (LICARIÃO, [199-?]). Assim sendo, "a imaginação pessoal de cada poeta na literatura de cordel se une à tradição para a criação das narrativas que são retratadas pelas xilogravuras" (MENEZES, 2010, p. 184). 
Nos tempos passados, as pessoas que não sabiam ler os cordéis conseguiam compreender 0 sentido sequencial e o conteúdo apresentado nesses folhetos por meio das imagens (FEBVRE; MARTIN, 1992). Observa-se, nesse sentido, a importância das xilogravuras para a disseminação da cultura popular e representação da escrita por meio das imagens, como forma de facilitar a compreensão das pessoas que não sabiam ou ainda não sabem ler. Elas se tornaram acessíveis às classes populares e são imprescindíveis tanto no processo de representação da narrativa de cordel como na construção histórica da cultura popular brasileira.

Em função disso, Mello (2016) discorre acerca da articulação sintagmática da gravura com 0 texto escrito e justifica a importância de um léxico pictórico ${ }^{3}$, de uma sintaxe figurativa ${ }^{4}$ ou da imagem performática acerca do tema tratado nesses recursos, tendo em vista que:

\begin{abstract}
A imagem não é apenas ilustração, ela é, nesses folhetos de exempla do cordel, o instrumento com o qual o paradigma solidifica-se, por ser um repertório extraverbal e paralinguístico. A imagem vai permitir a visualização do que se tenta modelar, transcodificando, transpondo intersermioticamente 0 texto linguístico à imagem pictórica e a imagem pictórica ao texto linguístico (MELLO, 2016, p. 256, grifo nosso).
\end{abstract}

Assim, o pensamento criador do artista no campo da xilogravura de folhetos de cordel é inspirado na poesia. Há uma notável fidelidade ao conteúdo essencial do folheto. "Isso significa dizer que o gravador não cria, num sentido de autonomia, de independência. Sua arte se faz sentir em função da obra, do texto. Ajuda, induz à percepção do fenômeno" (CARVALHO, 2014, p. 129). 0 fazer xilográfico, nessa perspectiva, pode ser relacionado com a atividade de representação temática da informação, haja vista o compromisso e a preocupação desse artista em condensar na imagem os assuntos principais contidos no folheto.

Desse modo, as xilogravuras unem os elementos da técnica com o refinamento de uma adequação de meios e mensagens iconográficas, no intuito de atingir níveis expressivos de descrições e manifestações com base em percepções visuais que se pluralizam de acordo com os aspectos históricos, éticos, morais, políticos, socioeconômicos e culturais dos seus leitores.

Portanto, diferentemente das análises de fotografias, a leitura pelo referente - pela coisa que representa algum objeto da realidade, ou seja, o "necessariamente real" de Barthes (1984) - não coaduna com os elementos contemplados nas xilogravuras. Elas não são elaboradas em função de algo

3 Vocabulário que represente e considere o conteúdo da imagem.

4 Sintaxe que contribui para a análise do assunto da xilogravura em literatura de cordel. 
necessariamente real, pois são consideradas também as construções mentais ou invenções (elementos imaginários) do poeta.

Além disso, as xilogravuras não são necessariamente espelhos do real, nem muito menos da própria realidade, elas apresentam elementos que podem ser relacionados a objetos e fatos inerentes a essa. Esse aspecto é o que representa o seu caráter de singularidade enquanto recurso imagético que retrata o rico imaginário da cultura popular e que necessita de métodos e técnicas específicas para a sua indexação.

\section{PERCURSO METODOLÓGICO}

Os procedimentos metodológicos desta pesquisa são empreendidos a partir da pesquisa bibliográfica para a fundamentação teórica do assunto estudado, seguido de um delineamento de caráter exploratório e descritivo com abordagem qualitativa - uma vez o seu objetivo geral consiste em apresentar uma proposta de metodologia para a indexação de imagens, em especial de xilogravuras de cordel, considerando o arcabouço teórico-metodológico da Semântica Discursiva.

\subsection{Semântica Discursiva}

A semântica, enquanto área do conhecimento, emergiu no final do século XX no intuito de responder as demandas da sociedade científica por meio do estudo do significado ou teoria da significação (FIORIN, 1999). Desse modo, o seu foco não está ligado apenas às palavras, mas também às orações, gestos, símbolos, imagens e entre outros elementos de significação.

Enquanto abordagem metodológica, a Semântica Discursiva foi idealizada por Algirdas Julien Greimas e busca atribuir sentido ao discurso com base no modelo teórico-metodológico denominado Percurso Gerativo da Significação (PGS) ou Percurso Gerativo do Discurso (PGD), cujo foco é o estudo da produção e interpretação de sentidos. Embora a noção de signo seja considerada, Greimas não parte do signo para estruturar e propor a sua metodologia, uma vez que são levadas em consideração as denominadas "figuras".

Para Fiorin (1999) "a noção de percurso gerativo de sentido constitui um simulacro metodológico para explicar o processo de entendimento, em que o leitor precisa fazer abstrações, a partir da superfície do texto, para poder entendê-Io". Portanto, esse modelo teórico-metodológico representa 
um processo que parte do nível simples ao mais complexo, são eles: profundo (ou fundamental), narrativo e discursivo.

Cada nível supracitado contém um elemento sintático e um elemento semântico, considerando que a sintaxe busca estudar questões relativas à estrutura do vocabulário e a semântica busca focar "nas regras que presidem às relações entre os vocábulos, as construções das orações e as relações interacionais" (ANTÔNIO, 2008, p.12).

Seguindo essa linha de raciocínio, nesta pesquisa são estudadas as contribuições da semântica de nível discursivo, no intuito de considerar os procedimentos de tematização e figurativização como subsídios para a construção da metodologia de indexação de imagens, em especial de xilogravuras de cordel.

A Semântica Discursiva integra duas formas básicas de discursos: os discursos concretos e os discursos abstratos. Eles não são antagônicos entre si, pois coexistem e estão interligados apresentando um caráter lógico que percorre do concreto (figuras) para o abstrato (temas). Desse modo, o discurso concreto construído com figuras é denominado figurativo. E o discurso abstrato edificado por temas é definido como temático.

Para Fiorin e Savioli (2003, p. 89) os textos figurativos "produzem um efeito de realidade, e por isso representam o mundo, criam uma imagem do mundo, com seus seres, seus acontecimentos". Os textos temáticos, por sua vez, "explicam as coisas do mundo, ordenam-nas, classificam-nas, interpretam-nas, estabelecem relações e dependências entre elas, fazem comentários sobre suas propriedades".

Nesse prisma, os textos figurativos dirigem-se a algum aspecto da realidade, criando imagens da mesma, bem como dos seres, das coisas, das ações, acontecimentos e qualidades associados a ela. Para Antônio (2008, p. 66) "quando fala-se mundo real devemos pensar também no mundo construído".

Tal como as figuras, os temas "também se encadeiam em percursos, isto é, em conjuntos organizados. São os percursos temáticos. Para apreender o tema geral, é preciso perceber esse encadeamento dos temas e depreender a unidade subjacente à diversidade" (FIORIN; SAVIOLI, 2003, p. 101).

Assim, os temas expressam elementos abstratos por meio de uma natureza conceitual representada por classes e categorizações, conforme explica Barbalho (2006, p. 88):

A tematização expressa elementos abstratos buscando explicar a realidade e representar 0 mundo através de um investimento conceptual. Os temas organizam, categorizam e ordenam a realidade significante de modo a permitir sua interpretação. Figuras e temas são para manter 
a coerência interna do texto, necessitam seguir um percurso ou encadeamento lógico de modo a gerar sentido. As figuras devem ser vistas através do conjunto por elas composto e não isoladamente.

Albuquerque (2011, p. 173, grifo da autora), por sua vez, apresenta as relações entre os níveis temático e figurativo da Semântica Discursiva:

\begin{abstract}
A semântica discursiva tem como componente a tematização - elementos abstratos presentes no texto - e a figurativização - elementos concretos presentes no texto - que dão concretude ao tema. As figuras do texto formam uma rede, uma trama que, para entendê-las, é necessário conhecer o primeiro nível temático assim como o nível figurativo em que palavras e expressões apresentam traços comuns de significação, que podem ser agrupados.
\end{abstract}

A relação entre as figuras apresentadas para a construção do sentido e, consequentemente, a identificação do tema atinente a elas é denominada por Albuquerque (2011) de "encadeamento de figuras". Portanto, a sequência dessas figuras resultante do seu agrupamento produz uma rede relacional, denominada no sistema semiótico como percurso figurativo, e expressa os temas subentendidos no texto - tornando viáveis as possibilidades significativas em um dado contexto.

Depreende-se, portanto, que os estudos que possuem maior conexão com a Semântica Discursiva e que contribuem significativamente para a Ciência da Informação são aqueles relacionados à Organização e Representação da Informação e do Conhecimento. Esses estudos, em conjunto, podem colaborar para o processo de análise e síntese do sentido das informações contidas em textos verbais e não verbais, considerando que os sujeitos possuem mentes interpretadoras que executam processos semióticos, interpretam e ressignificam diferentes visões de mundo apresentadas por estruturas conceituais.

Diante do exposto, a metodologia proposta nesta pesquisa contempla a discursivização semântica, privilegiando os processos de figurativização e tematização. Para tanto, aborda a análise de xilogravuras em níveis descritivos (figuras) e interpretativos (temas). As figuras consideram os aspectos denotativos, ou seja, aquilo que a xilogravura mostra de forma explícita (elementos concretos); e os temas levam em conta os aspectos conotativos (elementos abstratos), ou seja, aquilo que pode ser simulado pela xilogravura - associando-se ao processo de tematização.

Os temas não necessariamente precisam refletir o contexto ou significado "real" da xilogravura, mas o que essa pode (res)significar na concepção de quem a analisa, haja vista que a mesma inclui elementos reais e imaginários que fazem parte da cultura popular. Esses e outros elementos serão pontuados nos resultados desta pesquisa. 
Objetivando dar continuidade às descrições do percurso metodológico, a seguir é apresentado o material selecionado como corpus deste estudo.

\subsection{Material selecionado}

Considerando que o pensamento criador do artista no campo da xilogravura de folhetos de cordel é inspirado na poesia, foram selecionados os folhetos de cordel cujas xilogravuras e poesias foram produzidas pelo poeta e xilógrafo Marcelo Soares. A escolha desse poeta e xilógrafo está atrelada ao fato de que o mesmo é considerado um dos mais significativos poetas cordelistas da atualidade, assumindo a presidência de honra da Academia de Cordel do Vale do Paraíba.

Marcelo Soares é filho do poeta José Soares. Considerado o primeiro poeta repórter, elabora xilogravuras para folhetos de cordel há mais de 40 anos, tendo expandido as suas atividades ilustrando capas, livros, discos, cartazes de filmes, shows, teatro e outros ${ }^{5}$. Marcelo Soares foi o único xilógrafo brasileiro convidado para participar em 2015 do Encontro Mundial dos Artistas da Madeira ${ }^{6}$ em Istambul, Turquia, pela qualidade da madeira que utiliza em suas xilogravuras.

No período de fevereiro de 2018 a fevereiro de 2019 foi realizada uma busca da produção literária desse poeta e artista em unidades de informação que possuem acervos de cordéis na Paraíba. Nesse sentido, foram recuperados 109 títulos cujas xilogravuras e versos foram produzidos pelo poeta e xilógrafo Marcelo Soares. Nessa perspectiva, tais folhetos se configuram como universo desta pesquisa.

No intuito de analisar e indexar à luz da Semântica Discursiva xilogravuras que retratam temáticas diversificadas em capas de folhetos de cordel produzidos e publicados pelo poeta e xilógrafo supracitado, na pesquisa doutoral foi selecionada (dentre os cento e nove títulos) uma xilogravura para cada classe temática proposta por Albuquerque (2011). Essa pesquisadora propõe 27 classes temáticas para a indexação de folhetos de cordel à luz da Semântica Discursiva, são elas: agricultura; biografia e personalidades, bravura e valentia; cidade e vida urbana; Ciência; contos; crime; cultura; educação; esporte; erotismo; feitiçaria; fenômeno sobrenatural, história; homossexualismo; humor; intempéries; justiça; meio ambiente; moralidade; morte; peleja; poder; político e social; religião; romance; saúde/ doença.

5 Informação disponível em: http://rubensnobrega.com.br/2018/09/21/literal-de-cordel-agora-e-patrimonio-cultural-imaterial-do-brasil/. Acesso em: 21 mar. 2020.

6 Além de abordar aspectos relativos à técnica de Xilografia, esse evento tem como objetivo buscar novos horizontes para sanar problemas de desmatamento e ressaltar a importância do reflorestamento no mundo. Informação disponível em: https://www. facebook.com/search/top/?q=Marcelo\%20Soares\%20\%20encontro\%20da\%20madeira. Acesso em: 21 mar. 2020. 
Os temas e as classes temáticas propostas por Albuquerque (2011) também foram identificadas à luz da Semântica Discursiva, embora o seu foco tenha sido a análise dos versos dos folhetos de cordel. Com base nessa perspectiva, esses temas e classes temáticas foram considerados nesta pesquisa, tendo em vista a articulação sintagmática entre a xilogravura e os versos do folheto.

Após a análise das xilogravuras ilustradas nas capas dos 109 folhetos recuperados, percebeuse que as mesmas estão diretamente associadas a 17 classes temáticas propostas pela autora supracitada, cujas porcentagens são apresentadas a seguir: biografia e personalidades (10\%); bravura e valentia (13\%); cidade e vida urbana (5\%); contos (18\%); cultura (27\%); educação (3\%); erotismo (1\%); esporte (2\%); fenômeno sobrenatural (3\%); humor (1\%); meio ambiente (3\%); moralidade (2\%); morte (1\%); poder (3\%); político e social (4\%); religião (2\%); saúde/doença (2\%). Com base nesses dados, percebeu-se que a maioria das imagens analisadas retratam elementos relacionados à biografia e personalidades, bravura e valentia, contos e cultura.

Considerando que este artigo se trata de um recorte de pesquisa doutoral, o Quadro 2 a seguir apresenta as xilogravuras selecionadas para este trabalho, mediante amostra aleatória simples.

Quadro 1- Xilogravuras analisadas

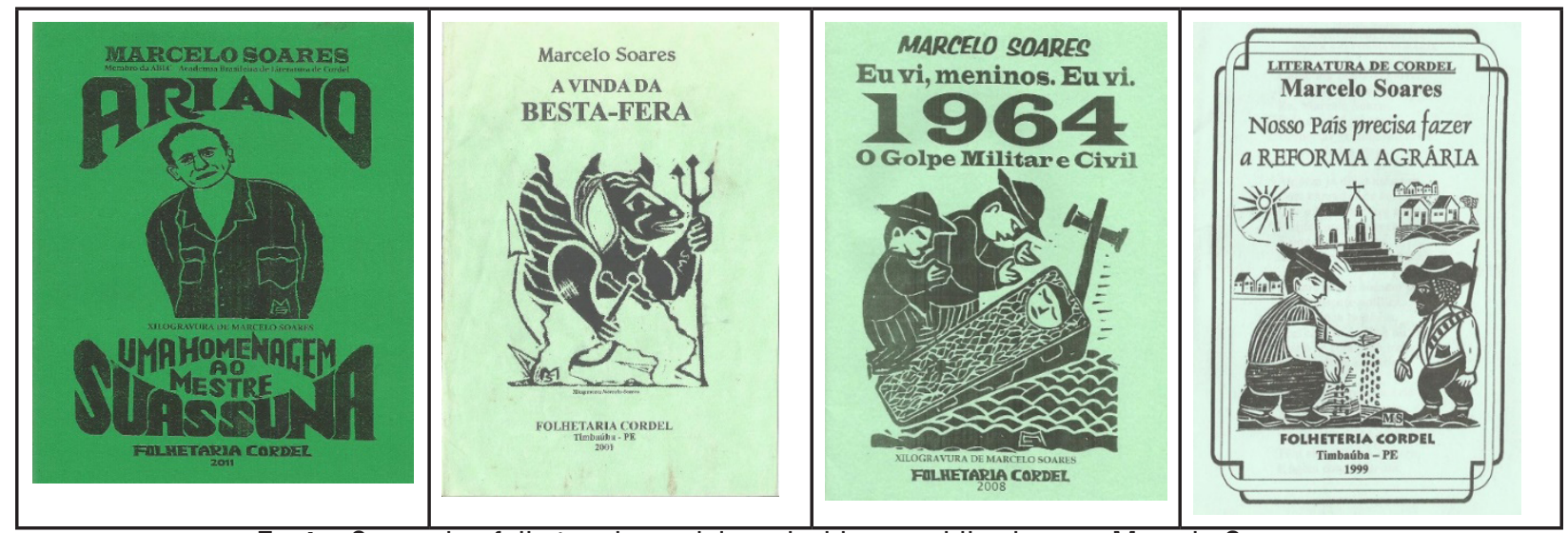

Fonte: Capas dos folhetos de cordel produzidos e publicados por Marcelo Soares.

Essa atividade de seleção do material foi efetuada para a posterior análise das xilogravuras e dos poemas sob o viés da Semântica Discursiva, no intuito de identificar figuras nas imagens e nos textos que subsidiem a identificação dos temas para a indexação desses recursos imagéticos. Com isso, são apresentadas as diretrizes que nortearão a atividade de identificação e seleção dos termos para representar o conteúdo temático das xilogravuras, considerando o arcabouço teórico-metodológico da Semântica Discursiva. 
Para dar segmento a essas considerações, a seguir é apresentada a síntese das etapas seguidas para atingir os objetivos geral e específicos da pesquisa.

\subsection{Etapas da pesquisa}

As etapas seguidas para atingir os resultados deste estudo são sintetizadas na Figura 1.

Figura 1- Etapas da pesquisa

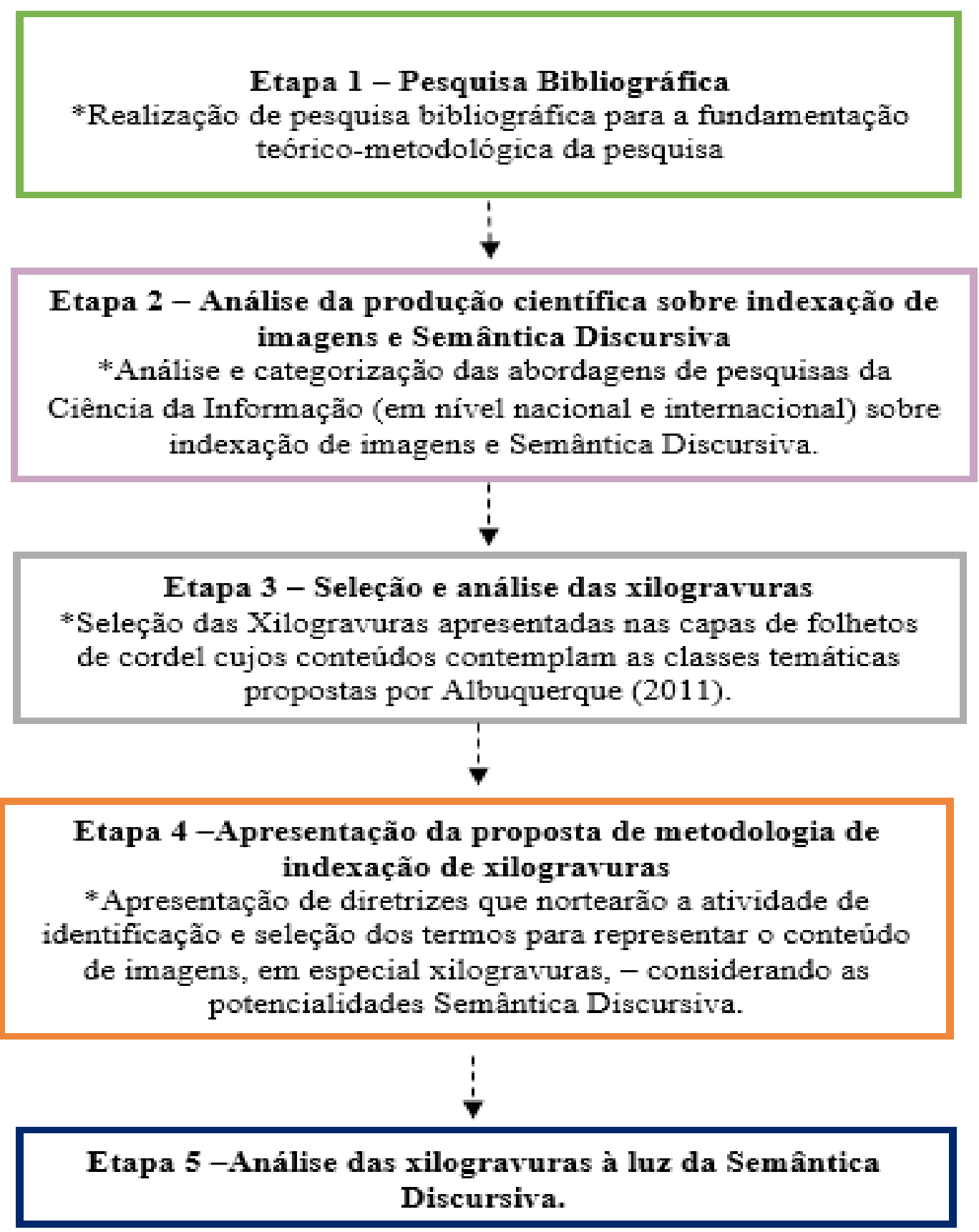

Fonte: Elaborado pela autora. 
Nesse entendimento, a seguir são apresentadas as diretrizes que norteiam a atividade de identificação e seleção dos termos para representar o conteúdo das imagens. Na oportunidade, são descritas as etapas que o profissional da informação deve considerar para indexar xilogravura com base na Semântica Discursiva.

\section{DIRETRIZES PARA A INDEXAÇÃO DE XILOGRAVURAS ALICERÇADAS NA SEMÂNTI- CA DISCURSIVA}

Conforme elucidado nos procedimentos metodológicos desta pesquisa, a Semântica Discursiva integra os discursos figurativos (concretos) e os discursos abstratos (temáticos). Neste estudo os discursos figurativos são tratados como figuras e correspondem aos elementos que se encontram visíveis na imagem, como por exemplo: personagens, ações, objetos, lugares, números, vocábulos, expressões, etc. Seguindo essa lógica, o procedimento de análise e identificação dessas figuras na imagem é denominado de figurativização.

Já os discursos abstratos correspondem aos temas, os quais são identificados a partir da confluência ou da imbricação das figuras identificadas em um dado recurso informacional, neste caso a imagem, no intuito de representar o seu conteúdo por meio de conceitos oriundos de classes e categorizações. Tal procedimento é denominado de tematização.

As figuras e os temas também podem ser identificados e extraídos em fontes adicionais relacionadas ao recurso imagético, como por exemplo: títulos, legendas, resumos, etc. Nesse caso, deve-se considerar a relação semântica entre as figuras extraídas dessas fontes e a imagem analisada.

Portanto, a figurativização e a tematização são procedimentos que pertencem à Semântica Discursiva e são componentes essenciais ao processo discursivização- resultado da interpretação de um vocábulo ou expressão com base em tais procedimentos. Por exemplo, o vocábulo "tortura" figurativiza o tema "sofrimento", que significa sensação consciente ou inconsciente de dor, mal-estar ou infelicidade. Portanto, "tortura" é uma figura associada ao tema "sofrimento", cujo significado apontado anteriormente corresponde à discursivização.

Essa lógica também vale para expressões, como por exemplo "desvio de verbas" figurativiza o tema "Corrupção", caracterizando o uso ilegal ou ilícito do poder político e financeiro em benefício próprio. Nessa lógica, a expressão "desvio de verbas" é uma figura associada ao tema "Corrupção" e 0 significado supracitado diz respeito à discursivização. 
A Figura 2 apresenta um mapa conceitual com a síntese dos aspectos discutidos acerca da Semântica Discursiva e das suas contribuições para a indexação de imagens como xilogravuras de cordel.

Figura 2- Mapa conceitual sobre Semântica Discursiva e indexação de imagens

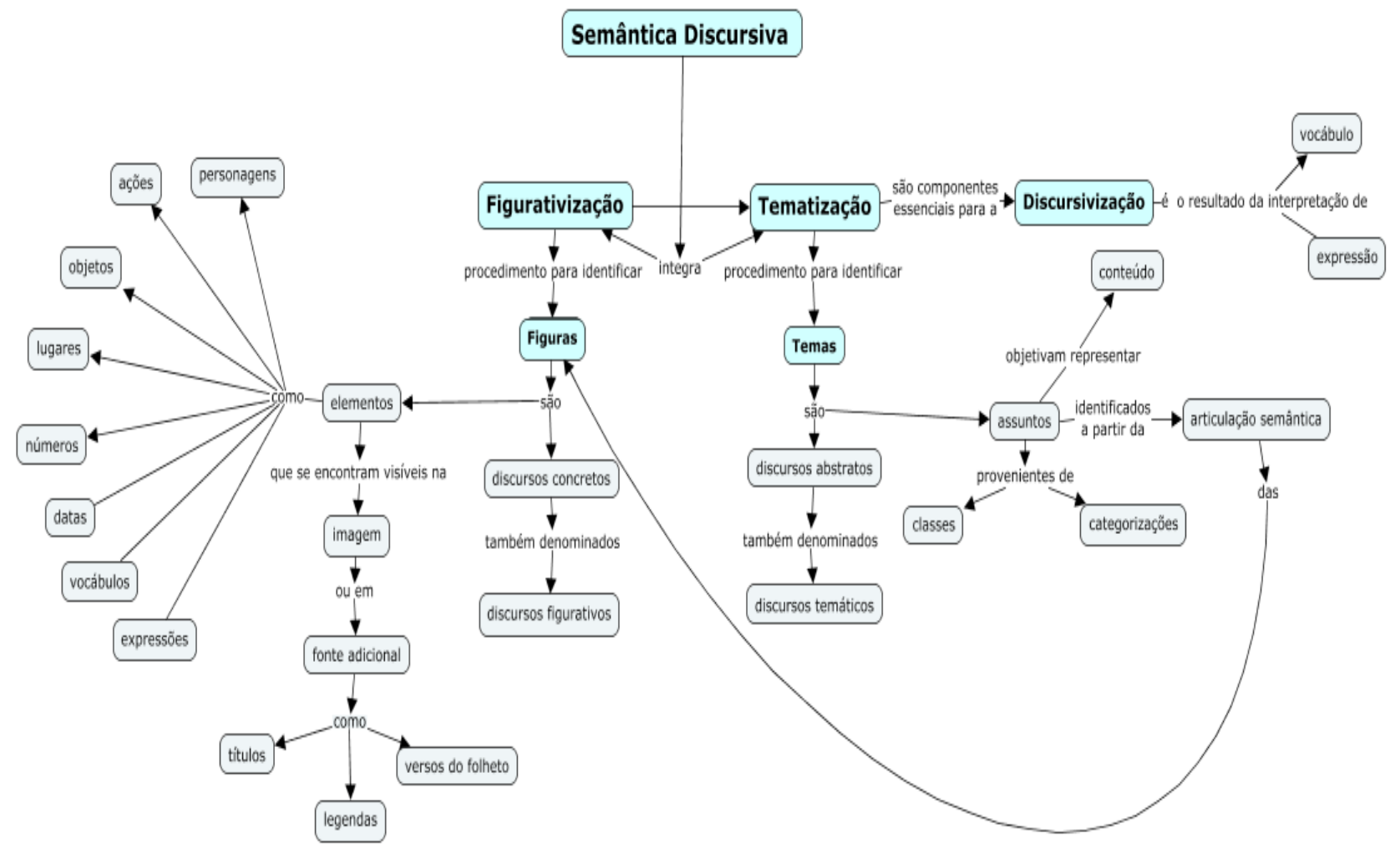

Fonte: Elaborado pela autora.

Como visto, no campo das xilogravuras de cordel, o pensamento criador do artista é inspirado na poesia, as narrativas visuais alimentam as narrativas textuais e articulam 0 seu uso e a sua interpretação por meio da complementaridade entre 0 texto e a imagem. Nesse entendimento, destaca-se a importância de o indexador realizar a leitura integral no título e nos versos do folheto cuja xilogravura está sendo analisada, como subsídio informacional e fonte adicional para a compreensão do seu conteúdo e dos elementos retratados nesse recurso imagético.

Diante disso, depreende-se que as xilogravuras de cordel se configuram como recursos imagéticos dotados de peculiaridades que devem ser consideradas na fase da organização e tratamento do seu conteúdo para fins de sua recuperação, acesso e uso por pesquisadores, artistas, colecionadores de arte e demais usuários. Esses recursos possuem funções mnemônicas associadas à condensação 
dos discursos presentes nos versos dos folhetos e funções metafóricas que viabilizam a multiplicação de sentidos e significados acerca do real e do imaginário popular.

Considerando as análises realizadas nesta pesquisa e os procedimentos supracitados, para a indexação de xilogravuras de cordel à luz da Semântica Discursiva, recomenda-se que o profissional da informação realize as seguintes etapas:

Figura 3- Etapas para a indexação de xilogravuras de cordel com base na Semântica Discursiva

1

- Leitura e análise da xilogravura

2

- Figurativização da xilogravura

- Coleta e análise de informações extrínsecas à imagem (leitura integral no

3 título e nos versos do folheto cuja xilogravura está sendo analisada)

- Figurativização das informações adicionais extraídas das fontes relacionadas à xilogravura

- Agrupamento das figuras extraídas da xilogravura e dos versos do folheto,

5 considerando as suas relações semânticas

- Identificação do(s) tema(s) por meio da articulação semântica entre as

6 figuras extraídas, para fins de indexação da xilogravura

7

- Identificação da classe temática do(s) assunto(s) da xilogravura analisada

Fonte: Elaborado pela autora.

Seguindo essa linha de raciocínio, verifica-se que para a indexação de xilogravuras de cordel, 0 indexador pode considerar sete etapas cujos procedimentos também contemplam os elementos da Semântica Discursiva, são elas: 
* $1^{\text {a }}$ etapa- Leitura e análise da xilogravura: com vistas à identificação de figuras;

${ }^{*} 2^{a}$ etapa- Figurativização da xilogravura: reconhecimento e extração dos elementos visíveis na imagem (personagens, ações, objetos, lugares, números, datas, vocábulos, expressões, etc.);

*3a etapa- Coleta e análise de informações extrínsecas à imagem: aquisição de análise de informações adicionais acerca da xilogravura como subsídios para o reconhecimento dos elementos retratados na imagem analisada. Nessa etapa, recomenda-se a leitura integral no título e nos versos do folheto cuja xilogravura está sendo analisada. Ademais, caso esses recursos estejam organizados em sistema colaborativo, as tags atribuídas pelos seus usuários também se configuram como fontes de informação adicional.

* $4^{\mathrm{a}}$ etapa- Figurativização das informações adicionais extraídas das fontes relacionadas à xilogravura: reconhecimento e extração de figuras na narrativa textual, ou seja, nos versos do folheto cuja xilogravura está sendo analisada. Essas figuras devem estar associadas aos personagens, ações, objetos, lugares, números, datas, vocábulos, expressões, etc. retratados na imagem;

${ }^{*} 5^{a}$ etapa- Agrupamento das figuras extraídas da xilogravura e dos versos do folheto, considerando as suas relações semânticas: reunião das figuras coletadas nas etapas anteriores e encadeamento das mesmas com base nas relações semânticas existentes entre si, no intuito de distinguir os elementos constituintes desses recursos e os seus respectivos conteúdos para fins de representação e recuperação;

${ }^{*} \sigma^{a}$ etapa- Identificação do(s) tema(s) por meio da articulação semântica entre as figuras extraídas: reconhecimento do(s) assunto(s) correspondente(s) à xilogravura, com base nos vocábulos e expressões agrupados na etapa anterior, para fins de indexação.

${ }^{*} 7^{a}$ etapa- Identificação da classe temática do(s) assunto(s) da xilogravura analisada: o(s) tema(s) identificados na etapa anterior são provenientes de classes e categorizações. Nesta etapa, o profissional indexador deve especificar qual a classe temática dos assuntos retratados na xilogravura.

0 Quadro 2 apresenta classes e categorizações que podem servir como referência para 0 profissional indexador na análise e indexação de xilogravuras, tendo em vista que contempla as características dos elementos e dos assuntos retratados nas imagens analisadas na pesquisa doutoral. Considerando o fato de que a xilogravura se configura como registro visual do que é descrito nos folhetos, o quadro também atualiza a descrição das classes e temas propostos por Albuquerque (2011). 
Quadro 2- Temas e classes temáticas associadas às xilogravuras

\begin{tabular}{|c|c|c|}
\hline CLASSES TEMÁTICAS & DESCRIÇÕES & TEMAS \\
\hline 1- Agricultura & $\begin{array}{l}\text { Xilogravuras cujas narrativas visuais representam } \\
\text { personagens agricultores, lavouras, engenhos, } \\
\text { técnicas de cultivo de plantas, política agrícola, } \\
\text { práticas de higiene, segurança e qualidade } \\
\text { alimentar, métodos usados na agricultura, de } \\
\text { culturas agrícolas e problemas ambientais. }\end{array}$ & $\begin{array}{l}\text { Adubação, Exploração, } \\
\text { Produção, Plantação }\end{array}$ \\
\hline $\begin{array}{l}\text { 2- Biografias e } \\
\text { Personalidades }\end{array}$ & $\begin{array}{l}\text { Xilogravuras cujas narrativas visuais retratam } \\
\text { figuras atuais ou atualizadas, tipos étnicos e } \\
\text { tipos regionais, etc.; pessoas homenageadas, } \\
\text { que se destacaram, no bem ou no mal, e que } \\
\text { se popularizaram na memória coletiva; tipos } \\
\text { humanos, tipos étnicos ou tipos regionais, que } \\
\text { aparecem na paisagem social. }\end{array}$ & $\begin{array}{l}\text { Inconfidência, Coragem, } \\
\text { Homenagem, Habilidade, } \\
\text { Reconhecimento }\end{array}$ \\
\hline 3- Bravura e Valentia & $\begin{array}{l}\text { Xilogravuras cujas narrativas visuais retratam } \\
\text { as bravuras dos(as) cangaceiros(as) e dos } \\
\text { "amarelinhos que ninguém dá nada por eles", } \\
\text { mas que são capazes de lutar e vencer homens } \\
\text { fortes. Valentia, coronelismo, banditismo e } \\
\text { jagunçagem, Lampião, Maria Bonita, Lídia, } \\
\text { Antônio Silvino, Corisco, entre outros. } \\
\end{array}$ & $\begin{array}{l}\text { Violência, Vitória, Cangaço, } \\
\text { Banditismo, Hesitação, Luta, } \\
\text { Crueldade, Prisão, Valentia, } \\
\text { Salvação, Bravura, Liderança }\end{array}$ \\
\hline 4-Cidade e Vida Urbana & $\begin{array}{l}\text { Xilogravuras cujas narrativas visuais retratam } \\
\text { situações do cotidiano, aspectos da vida urbana, } \\
\text { cidades, Estados, bairros, bares, cabarés, etc. }\end{array}$ & $\begin{array}{l}\text { Memória, Urbanismo, } \\
\text { Culinária, Desenvolvimento, } \\
\text { Beleza }\end{array}$ \\
\hline 5-Ciência & $\begin{array}{l}\text { Xilogravuras cujas narrativas visuais retratam } \\
\text { sobre o saber, conhecimento de certas coisas que } \\
\text { servem à condução da vida ou à dos negócios; } \\
\text { dos conhecimentos adquiridos pelo estudo ou } \\
\text { pela prática; da hierarquização, organização } \\
\text { e síntese dos conhecimentos através de } \\
\text { fenômenos, princípios gerais (teorias, leis, etc.). }\end{array}$ & $\begin{array}{l}\text { Ciência, Tecnologia, } \\
\text { Astronomia, Descobertas, } \\
\text { Matemática, Cosmologia, } \\
\text { Heliocentrismo, Inseminação }\end{array}$ \\
\hline 6-Contos & $\begin{array}{l}\text { Xilogravuras cujas narrativas visuais retratam } \\
\text { personagens e elementos míticos descritos } \\
\text { em contos populares, estórias ou lendas de } \\
\text { uma determinada região (dragões, saci-pererê, } \\
\text { mulher-cobra, mulas sem cabeça, bumba- } \\
\text { meu-boi, sereias, etc.), contos de "fadas", } \\
\text { "histórias de trancoso" e "fábulas". Nesse caso, } \\
\text { a realidade atribuída à imagem se configura } \\
\text { como um produto do imaginário popular, pois } \\
\text { são provenientes de invenções fantasiadas na } \\
\text { cognição dos sujeitos. }\end{array}$ & $\begin{array}{l}\text { Ganância, Fantasia, Proteção, } \\
\text { Ilusão, Honestidade, Infração, } \\
\text { Esperteza, Aparência, } \\
\text { Crueldade, Invenção, Riqueza, } \\
\text { Encantamento, Brincadeiras, } \\
\text { Sofrimento, Mitologia, Poder, } \\
\text { Paralisação, Magia, Mistério } \\
\text { Transformação, Imaginação, } \\
\text { Iluminação, Canto, } \\
\text { Comunicação, Personificação, } \\
\text { Armadilha, Sonoridade, } \\
\text { Punição, Eternidade, Luta, } \\
\text { Ofensa, Esforço }\end{array}$ \\
\hline
\end{tabular}




\begin{tabular}{|c|c|c|}
\hline 7-Crime & $\begin{array}{l}\text { Xilogravuras cujas narrativas visuais retratam } \\
\text { cenas que violam uma norma moral ou lei penal } \\
\text { incriminadora. Ação ou omissão que se proíbe e } \\
\text { se procura evitar, ameaçando-a com pena, porque } \\
\text { constitui ofensa (dano ou perigo) a um bem } \\
\text { jurídico individual ou coletivo. }\end{array}$ & $\begin{array}{l}\text { Assassinato, Maldade, } \\
\text { Infração, Chacina, Cilada, } \\
\text { Massacre, Terrorismo, } \\
\text { Criminalidade, Agressão, } \\
\text { Perversão, Castração }\end{array}$ \\
\hline 8-Cultura & $\begin{array}{l}\text { Xilogravuras cujas narrativas visuais expressam } \\
\text { a cultura popular por meio de representações } \\
\text { de manifestações artísticas, valores, tradições, } \\
\text { atividades, modos de agir, costumes e instruções } \\
\text { de um povo- marcando a identidade de uma } \\
\text { região ou de um país (festas e folguedos } \\
\text { populares, São João, vaquejada, artesanato etc.). }\end{array}$ & $\begin{array}{l}\text { Cultura, Manifestação } \\
\text { artística, União, Valores, } \\
\text { Imaginação, Improviso, } \\
\text { Sentido, Expressão, } \\
\text { Entretenimento, Composição, } \\
\text { Língua, Imortalidade, } \\
\text { Criatividade, Divulgação, } \\
\text { Ufanismo, } \\
\text { Tradição, Sonoridade }\end{array}$ \\
\hline 9-Educação & $\begin{array}{l}\text { Xilogravuras cujas narrativas visuais retratam } \\
\text { elementos e aspectos concernentes ao ensino e } \\
\text { à educação como processo contínuo que orienta } \\
\text { e conduz o indivíduo a novas descobertas, a fim } \\
\text { de tornar suas próprias decisões, dentro de suas } \\
\text { capacidades (escolas, universidades, sala de } \\
\text { aulas, quadros, livros, etc.). }\end{array}$ & $\begin{array}{l}\text { Adivinhação, Cidadania, } \\
\text { Conhecimento, Duelo, } \\
\text { Aprendizagem, Arte, } \\
\text { Imaginação, Significação, } \\
\text { Educação, Ensino }\end{array}$ \\
\hline 10-Erotismo & $\begin{array}{l}\text { Xilogravuras cujas narrativas visuais não têm } \\
\text { a intenção de ofender a moralidade pública. } \\
\text { Imagens que têm o órgão sexual masculino } \\
\text { ou feminino como principal temática, bem } \\
\text { como narrativas visuais associadas à nudez, } \\
\text { libertinagem, prostituição e sexualismo. } \\
\end{array}$ & $\begin{array}{l}\text { Libertinagem, Prostituição, } \\
\text { Exibição, Sexualismo, } \\
\text { Promiscuidade, Desejo }\end{array}$ \\
\hline 11-Esporte & $\begin{array}{l}\text { Xilogravuras cujas narrativas visuais retratam } \\
\text { elementos e aspectos relativos ao esporte, às } \\
\text { atividades físicas, formais ou informais, que } \\
\text { visam à melhoria das capacidades físicas e } \\
\text { mentais, fomentam as relações sociais ou visam } \\
\text { obter resultados na competição a todos os níveis } \\
\text { (símbolos e mascotes de clubes esportivos, } \\
\text { torcidas, recursos utilizados em práticas } \\
\text { esportivas, modalidades esportivas, etc.). } \\
\end{array}$ & $\begin{array}{l}\text { Competição, Vitória, } \\
\text { Conquista, Desportos, Defesa, } \\
\text { Torcida }\end{array}$ \\
\hline 12-Feitiçaria & $\begin{array}{l}\text { Xilogravuras cujas narrativas visuais retratam } \\
\text { feiticeiros, ações de bruxaria, sortilégio, malefício, } \\
\text { bem como atividades e elementos associados à } \\
\text { temática. }\end{array}$ & $\begin{array}{l}\text { Bruxaria, Magia, } \\
\text { Transformação }\end{array}$ \\
\hline
\end{tabular}




\begin{tabular}{|c|c|c|}
\hline $\begin{array}{c}\text { 13-Fenômeno } \\
\text { sobrenatural }\end{array}$ & $\begin{array}{l}\text { Xilogravuras cujas narrativas visuais representam } \\
\text { fenômenos que não tenham uma causa natural, } \\
\text { coisas malignas, mundo espiritual, fenômenos } \\
\text { paranormais, espiritualidade. }\end{array}$ & $\begin{array}{l}\text { Divindade, Maldição, } \\
\text { Sobrenatural, Morte, } \\
\text { Mediunidade, Divino, } \\
\text { Assombração, Punição, } \\
\text { Espiritual, Sofrimento, } \\
\text { Fantasia, Profanidade }\end{array}$ \\
\hline 14-História & $\begin{array}{l}\text { Xilogravuras cujas narrativas visuais retratam } \\
\text { elementos e fatos históricos (como guerra, } \\
\text { escravidão, revolução, descobrimento, massacre, } \\
\text { independência, etc.). }\end{array}$ & $\begin{array}{l}\text { Invasão, Revolução, } \\
\text { Colonização, Liberdade, } \\
\text { Liderança, Desenvolvimento, } \\
\text { Escravidão, Guerra, } \\
\text { Doutrinamento, Criação, } \\
\text { Confronto, Descobrimento, } \\
\text { Massacre } \\
\text { Independência }\end{array}$ \\
\hline 15-Homossexualidade & $\begin{array}{l}\text { Xilogravuras cujas narrativas visuais retratam } \\
\text { experiências sexuais, afetivas e românticas, } \\
\text { principalmente, entre personagens do mesmo } \\
\text { sexo. }\end{array}$ & $\begin{array}{l}\text { Transformismo } \\
\text { Homossexualidade }\end{array}$ \\
\hline 16-Humor & $\begin{array}{l}\text { Xilogravuras cujas narrativas visuais retratam } \\
\text { elementos e situações cômicas, piadas. }\end{array}$ & $\begin{array}{l}\text { Odor, Gozação, } \\
\text { Temperamento, Diversão, } \\
\text { Humor, Sofrimento }\end{array}$ \\
\hline 17-Intempéries & $\begin{array}{l}\text { Xilogravuras cujas narrativas visuais retratam } \\
\text { fenômenos de natureza relacionados a secas, } \\
\text { inundações, tempestades, catástrofes, terremotos } \\
\text { e outros, os quais podem ser vistos como castigo } \\
\text { divino aos aspectos dos homens. Do êxodo rural. } \\
\text { O fenômeno ocorre quando os habitantes do } \\
\text { campo visam obter condições de vida melhor. }\end{array}$ & $\begin{array}{l}\text { Seca, Destruição, Inundação, } \\
\text { Sofrimento, } \\
\text { Migração, Sismologia, } \\
\text { Temperatura }\end{array}$ \\
\hline 18-Justiça & $\begin{array}{l}\text { Xilogravuras cujas narrativas visuais retratam } \\
\text { símbolos e elementos relacionados à justiça } \\
\text { como princípio moral, prática de atos e/ou } \\
\text { decisões que corrijam uma situação ou punam } \\
\text { uma falta, de forma a beneficiar aqueles que } \\
\text { fizeram por merecer ser beneficiados ou a punir } \\
\text { aqueles que ofenderam física e/ou moralmente } \\
\text { outra(s) pessoas(s). }\end{array}$ & $\begin{array}{l}\text { Punição, Legislação, } \\
\text { Adoção, Liberdade, Justiça }\end{array}$ \\
\hline 19-Meio Ambiente & $\begin{array}{l}\text { Xilogravuras cujas narrativas visuais retratam o } \\
\text { conjunto de unidades ecológicas que funcionam } \\
\text { como um sistema natural sem a intervenção } \\
\text { do homem, incluindo vegetação, animais, } \\
\text { microorganismos, solo, rochas, atmosfera e } \\
\text { fenômenos naturais. Poluição. Ecologia. }\end{array}$ & $\begin{array}{l}\text { Natureza, Poluição, } \\
\text { Temperatura, Destruição, } \\
\text { Infração, Vida, Plantação, } \\
\text { Liberdade, Extinção }\end{array}$ \\
\hline
\end{tabular}




\begin{tabular}{|c|c|c|}
\hline 20-Moralidade & $\begin{array}{l}\text { Xilogravuras cujas narrativas visuais representam } \\
\text { aspectos concernentes às normas, princípios e } \\
\text { valores, segundo o qual são regulamentadas as } \\
\text { relações mútuas entre os indivíduos ou entre } \\
\text { estes e a comunidade, de tal maneira que estas } \\
\text { normas, dotadas de um caráter histórico e social, } \\
\text { sejam acatadas livre e conscientemente por } \\
\text { uma convicção íntima e não de uma maneira } \\
\text { mecânica, externa ou impessoal. Ex.: imagens } \\
\text { que representam traição, fidelidade, abandono, } \\
\text { sedução, irracionalidade, bigamia, hábitos, } \\
\text { safadeza e estilo. }\end{array}$ & $\begin{array}{l}\text { Traição, Abandono, } \\
\text { Sedução, Irracionalidade, } \\
\text { Hábito, Degustação, } \\
\text { Geração, Fidelidade, } \\
\text { Estilo, Maldição, } \\
\text { Comportamento, } \\
\text { Ostentação, Escândalo, } \\
\text { Bigamia, Destino, } \\
\text { Julgamento, Safadeza } \\
\text { Violência }\end{array}$ \\
\hline 21- Morte & $\begin{array}{l}\text { Xilogravuras cujas narrativas visuais representam } \\
\text { elementos associados ao término da vida de } \\
\text { um organismo, como também do estado desse } \\
\text { organismo depois do evento. }\end{array}$ & $\begin{array}{l}\text { Morte, Assassinato, Luto, } \\
\text { Sofrimento }\end{array}$ \\
\hline 22-Peleja & $\begin{array}{l}\text { Xilogravuras cujas narrativas visuais representam } \\
\text { folhetos de "criação", escritos, em sua maioria, } \\
\text { em homenagem a um (a) amigo (a) poeta. } \\
\text { Contam os seus autores que imaginam, de início, } \\
\text { um encontro em cada de um fazendeiro (o desafio } \\
\text { entre dois "bambas"), encomendando de pronto } \\
\text { o clássico "clichê" de madeira, representando as } \\
\text { figuras de dois cantadores sentados, dedilhando } \\
\text { a viola em desafio, gravura comumente } \\
\text { encontradas nas capas das publicações do } \\
\text { gênero. }\end{array}$ & $\begin{array}{l}\text { Peleja, Desafio, Expressão, } \\
\text { Discussão, Comunicação }\end{array}$ \\
\hline 23-Poder & $\begin{array}{l}\text { Xilogravuras cujas narrativas visuais representam } \\
\text { temas que envolvem discussões éticas ou morais } \\
\text { associadas ao poder político, desvio e abuso de } \\
\text { poder político, do poder executivo, do estado e } \\
\text { governo. }\end{array}$ & $\begin{array}{l}\text { Liberdade, Economia, } \\
\text { Opressão, Revolução, } \\
\text { Política, Poder, } \\
\text { Despotismo, Governo, } \\
\text { Utopia, Disputa, } \\
\text { Promessa, Corrupção, } \\
\text { Ambição, Destruição, Eleição, } \\
\text { Privatização, } \\
\text { Política salarial, Impunidade, } \\
\text { Insegurança }\end{array}$ \\
\hline
\end{tabular}




\begin{tabular}{|c|c|c|}
\hline 24-Político e social & $\begin{array}{l}\text { Xilogravuras cujas narrativas visuais tratam "do } \\
\text { que se vê em políticas" e refletem o desencanto } \\
\text { do povo com falsas promessas de alguns dos } \\
\text { seus representantes. Participação social enquanto } \\
\text { possibilidade para o exercício da cidadania. } \\
\text { Imagens que representam elementos políticos } \\
\text { e sociais, como classes sociais, desigualdades } \\
\text { sociais, luta de classes, inclusão social, reformas, } \\
\text { etc. }\end{array}$ & $\begin{array}{l}\text { Subserviência, Sofrimento, } \\
\text { Corrupção, Sobrevivência, } \\
\text { Ambição, Discriminação, } \\
\text { Fiscalização, Desarmamento, } \\
\text { Transformação, } \\
\text { Descobrimento, Classe social, } \\
\text { Vida, Adoção, } \\
\text { Reciclagem, Falsidade, } \\
\text { Infração, Vontade, Estímulo, } \\
\text { Lembrança, } \\
\text { Fofoca, Remuneração, } \\
\text { Desigualdade, Ostentação, } \\
\text { Civilização, Contribuição, } \\
\text { Organização, Sorte, } \\
\text { Azar, Inclusão social, } \\
\text { Conscientização, } \\
\text { Desigualdade social, } \\
\text { Organização, Recordação, } \\
\text { Transporte, Beleza, } \\
\text { Expulsão, Soberania, } \\
\text { Comunicação, Posse, } \\
\text { Segurança, Esperança, } \\
\text { Abandono, Emancipação, } \\
\text { Separação, Concorrência, } \\
\text { Vaidade, Mesquinhez, }\end{array}$ \\
\hline
\end{tabular}




\begin{tabular}{|c|c|c|}
\hline 25-Religião & $\begin{array}{l}\text { Xilogravuras cujas narrativas visuais retratam } \\
\text { ideias religiosas baseadas na tradição cristã, } \\
\text { com histórias de Jesus ou da vida dos Santos } \\
\text { (Padre Cícero, Nossa Senhora das Graças, Nossa } \\
\text { Senhora Aparecida, etc.), apresentando elementos } \\
\text { relacionados à fé, evangelização, divindade, } \\
\text { salvação, profecia, crucificação, pregação, } \\
\text { cristianismo, devoção, etc. }\end{array}$ & $\begin{array}{l}\text { Fé, Evangelização, } \\
\text { Santidade, Maternidade, } \\
\text { Santificação, Perdão, } \\
\text { Bondade, Transgressão, } \\
\text { Divindade, Salvação, } \\
\text { Regeneração, Libertação, } \\
\text { Humildade, Aconselhamento, } \\
\text { Profecia, Imaginação, } \\
\text { Criação, Crucificação, } \\
\text { Pregação, Cristianismo, } \\
\text { Transformação, Sermão, } \\
\text { Devoção, Ensinamentos, } \\
\text { Natividade }\end{array}$ \\
\hline 26-Romance & $\begin{array}{l}\text { Xilogravuras cujas narrativas visuais retratam } \\
\text { elementos concernentes ao amor, sofrimento e } \\
\text { fidelidade. }\end{array}$ & $\begin{array}{l}\text { Sentimento, União, } \\
\text { Sofrimento, Rejeição, } \\
\text { Honra, Sobrenatural, } \\
\text { Escravidão, Destino, } \\
\text { Perdão, Morte, Amor }\end{array}$ \\
\hline 27-Saúde. Doença & $\begin{array}{l}\text { Xilogravuras cujas narrativas visuais retratam o } \\
\text { estado de completo bem-estar físico, mental e } \\
\text { social. Distúrbios das funções de um órgão, da } \\
\text { psique ou do organismo humano. }\end{array}$ & $\begin{array}{l}\text { Amamentação, Saúde, } \\
\text { Higiene, Transformação, } \\
\text { Enfermidade, Prevenção, } \\
\text { Doença, Cura, Tratamento, } \\
\text { Nutrição, Deformação }\end{array}$ \\
\hline
\end{tabular}

Fonte: Adaptado pela autora com base em Albuquerque (2011).

Portanto, considera-se que os temas, as classes temáticas e as suas respectivas descrições, adaptadas e apresentadas anteriormente, objetivam orientar o profissional indexador no que concerne à identificação dos conteúdos representados em imagens como as xilogravuras, indicando os personagens, elementos e aspectos entalhados - os quais devem ser analisados no momento da indexação. Entretanto, é importante ressaltar que outras características, elementos e temas também 
podem ser acrescidos às descrições e às classes temáticas supracitadas, considerando a criatividade dos xilógrafos em representar o imaginário e a cultura popular - contemplando assim os preceitos associados ao conceito de hospitalidade cultural 7 .

As diretrizes apresentadas anteriormente são aplicadas nesta pesquisa considerando o fato de que as práticas de análise de xilogravuras, assim como as demais tipologias de recursos imagéticos, não devem estar pautadas no debate entre o "certo" e 0 "errado", mas sim entre as possibilidades plausíveis de representação, mediante observações contextuais. Desse modo, considera-se também a importância de o profissional da informação conhecer as características do banco de imagens, bem com as funções e usos das xilogravuras no contexto da unidade de informação.

$\mathrm{Na}$ indexação de xilogravuras também deve ser considerada a diversidade de significados, interpretações e representações existentes no imaginário e na cultura popular. Portanto, acredita-se que a garantia cultural e a garantia ética podem corroborar para a inclusão da noção de diversidade cultural às práticas de representação dessas imagens. Para tanto, faz-se necessário que o profissional indexador, ao analisar a imagem e os versos dos folhetos, tente compreender as sinonímias e os símbolos contidos nessas fontes de informação. Por exemplo, na literatura de cordel 0 vocábulo "corno" designa a pessoa que sofreu traição amorosa pelo seu parceiro ou parceira. Tal significado também está associado aos vocábulos “chifrudo", "cornudo", "galhudo", os quais se configuram como sinonímias. Já no âmbito das xilogravuras esses vocábulos estão relacionados à ilustração de uma pessoa com chifres de boi em sua cabeça.

Entendendo isso, nota-se que as práticas de indexação e classificação devem considerar os aspectos éticos e culturais, sobretudo pelo discurso em que uma comunidade ou grupo objetiva solidificar a sua identidade.

Tendo em vista que, em linhas gerais, as xilogravuras em cordéis objetivam (ou se propõem a) representar o conteúdo dos folhetos, nesta pesquisa recomenda-se a leitura integral do título e dos versos do folheto como subsídio informacional para a compreensão do conteúdo dessas imagens. Caso 0 indexador considere essas diretrizes para a realização da indexação de outras tipologias de recursos imagéticos (como fotografias, obras de arte, etc.), faz-se necessário que o mesmo identifique

7 Como visto no referencial teórico desta pesquisa, o conceito de hospitalidade cultural está associado à capacidade de um Sistema de Organização do Conhecimento acrescentar conceitos desconsiderados, de maneira intencional ou não, acolhendo várias garantias e culturas, objetivando representar, devidamente, as crenças de quaisquer pessoas, grupos ou comunidades (BEGHTOL, 2005). 
quais as fontes de informação devem ser pesquisadas como subsídio informacional, de acordo com as suas respectivas características.

\section{INDEXAÇÃO DE XILOGRAVURAS À LUZ DA SEMÂNTICA DISCURSIVA}

A seguir é apresentada a análise e a indexação das xilogravuras selecionadas para este artigo.

\section{Classe "Biografias e personalidades"}

Como visto, no campo de indexação de imagens é possível que o profissional se depare com a complexidade de traduzir o conteúdo visual desses recursos em descrições verbais. Assim como os demais tipos de imagens, informações como nomes e características de pessoas, por exemplo, nem sempre podem ser identificados a partir da narrativa visual presente nas xilogravuras - 0 que requer a aquisição de informações extrínsecas a esse recurso para subsidiar a prática da indexação, como observa-se na Figura 4.

Figura 4 - Capa do folheto: "Ariano Suassuna na voz de poetas populares"

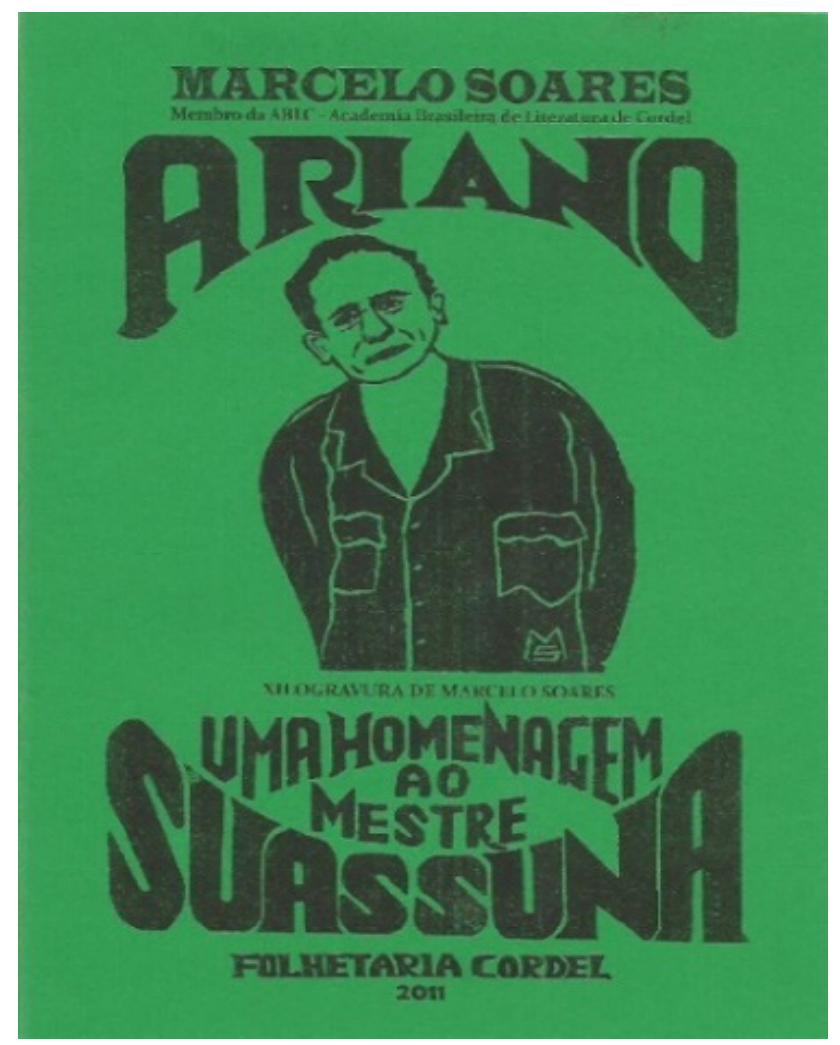

Fonte: Soares (2014). 
Ao analisar a imagem apresentada, verificou-se que a xilogravura representa traços de um homem com o rosto inclinado e traje despojado, carregando em sua aparência características da simplicidade. Notou-se que a mesma se trata da representação de uma pessoa homenageada, podendo ser uma figura pública, escritor, político, artista, poeta, por exemplo. Ou seja, inicialmente podem surgir dúvidas, por parte de quem analisa a xilogravura, em relação à pessoa representada na xilogravura.

Considerando o procedimento de figurativização, o mapa conceitual a seguir elenca as figuras supracitadas (personagem e características), as quais foram reconhecidas na xilogravura mediante a análise da narrativa visual presente nesse recurso imagético.

Figura 5 - Figurativização da xilogravura do folheto "Ariano Suassuna na voz de poetas populares"

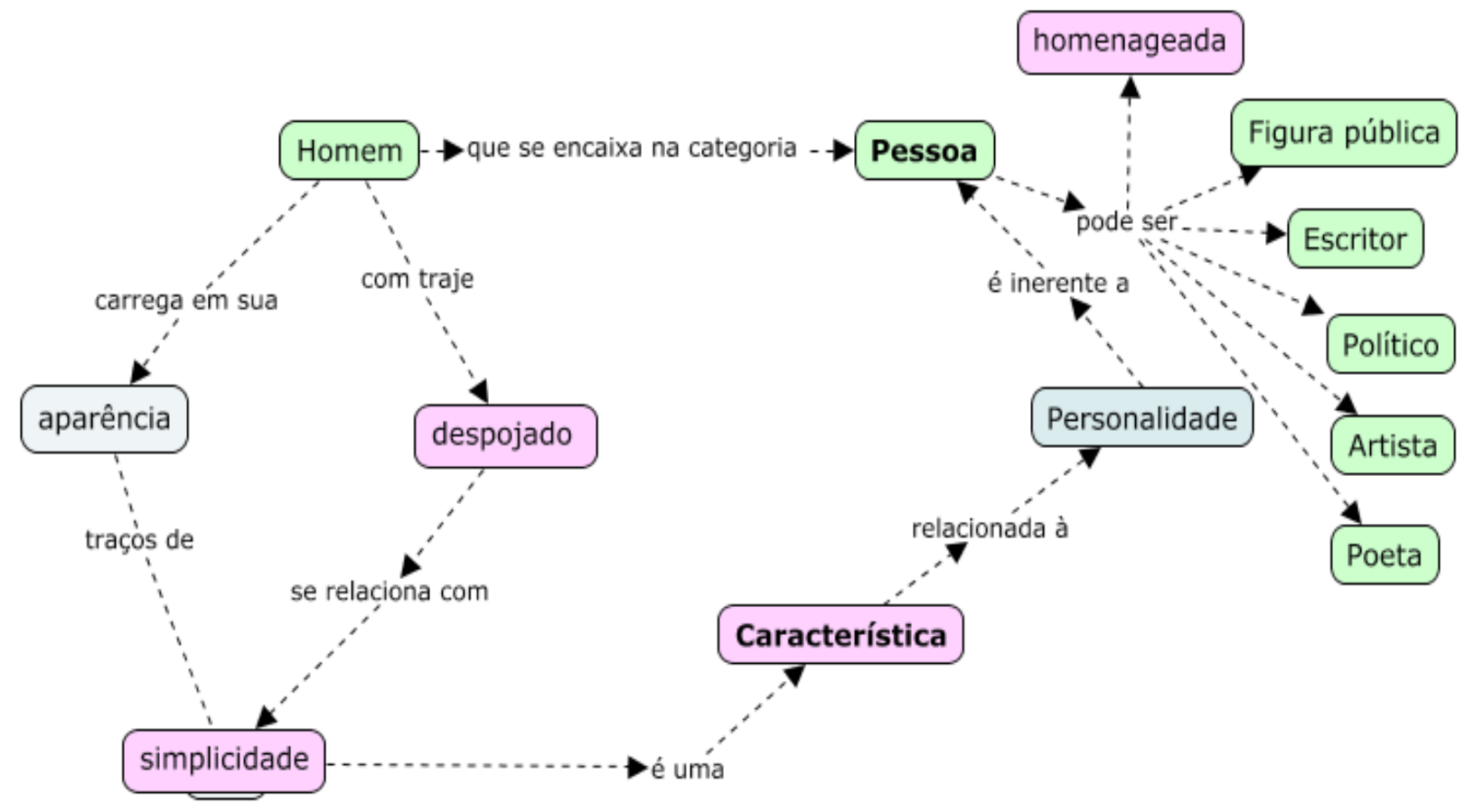

Fonte: Elaborado pela autora.

Para a aquisição de informações adicionais sobre o personagem representado na xilogravura analisada, fez-se necessária à leitura do título e dos versos do folheto. Ao ler integralmente o folheto, verificou-se que o mesmo foi publicado em setembro de 2014, tem como título "Ariano Suassuna na voz de poetas populares" e trata sobre a biografia e os traços de personalidade de Ariano Suassuna escritor, artista, dramaturgo e poeta brasileiro cujas obras agregam elementos de diversos movimentos. 
Ariano nasceu em 1927 e faleceu em 23 de julho de 2014, foi um dos grandes defensores da cultura popular e um verdadeiro mestre em arte e simplicidade.

Objetivando auxiliar no processo de indexação da xilogravura analisada, a ilustração a seguir evidencia a articulação semântica entre os elementos vislumbrados na xilogravura e nos versos (septilha e décima) do folheto.

Figura 6 - Articulação semântica entre xilogravura e versos do folheto "Ariano Suassuna na voz de poetas populares"

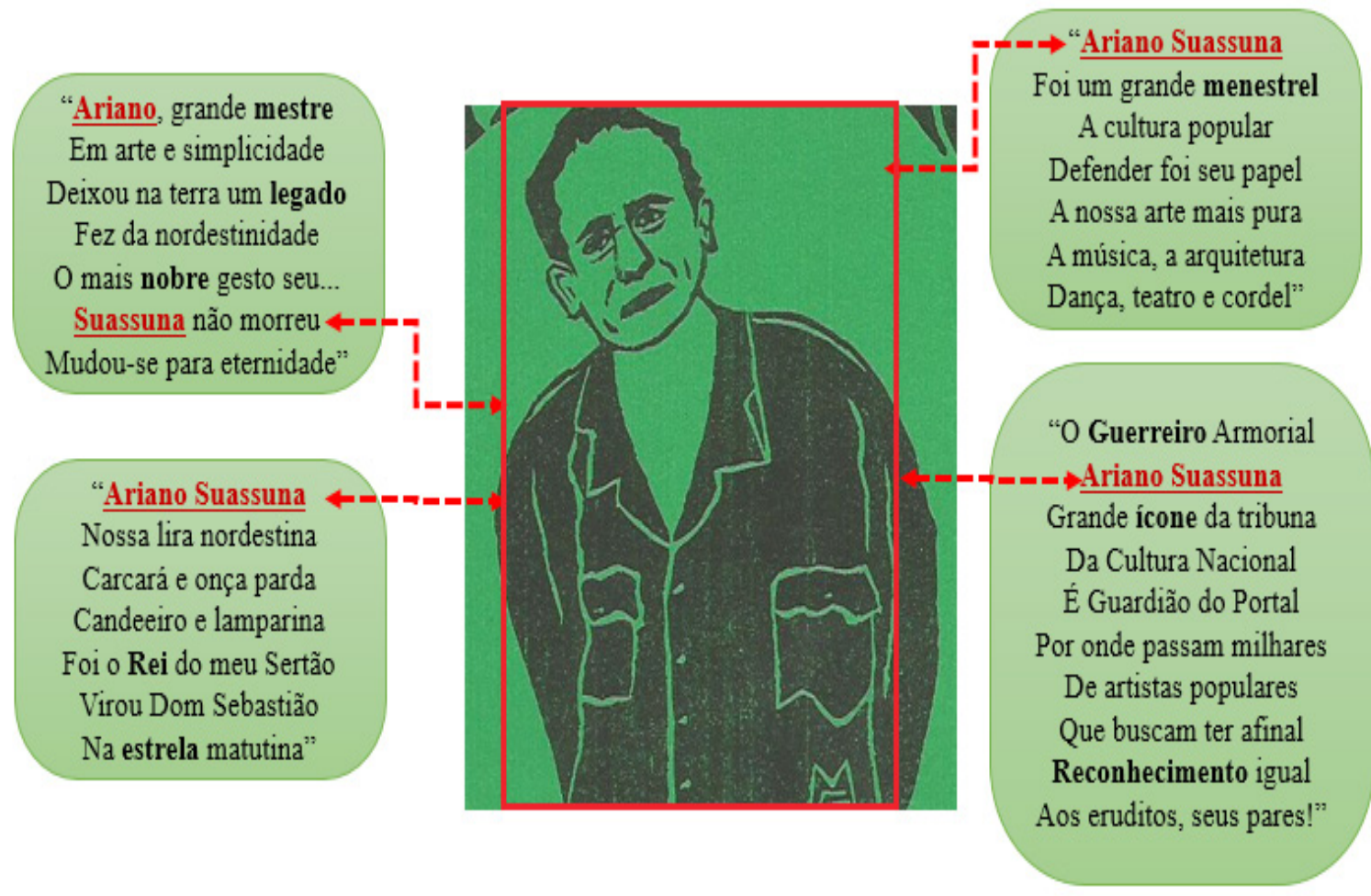

Fonte: Elaborado pela autora.

Percebeu-se, portanto, que o vocábulo "Ariano Suassuna" se configura como o nome da pessoa mencionada no folheto e que, por sua vez, também se encontra representada na xilogravura. Já os vocábulos com destaque em negrito dizem respeito às figuras apresentadas nos versos dos folhetos, as quais podem estar associadas ao(s) tema(s) da imagem.

0 Quadro 3 apresenta a síntese dos elementos apontados anteriormente, elencando as figuras extraídas da narrativa visual e dos versos do folheto. Na oportunidade, são apresentados os temas identificados de acordo com 0 encadeamento dessas figuras para indexar a imagem em questão, bem como a classe temática que a mesma está associada. 
Quadro 3 - Figurativização e Tematização da Xilogravura do folheto "Ariano Suassuna na voz de poetas populares"

\begin{tabular}{|c|c|c|c|c|}
\hline $\begin{array}{l}\text { FIGURAS } \\
\text { EXTRAIIDAS DA } \\
\text { IMAGEM }\end{array}$ & $\begin{array}{l}\text { VERSOS QUE APRESENTAM } \\
\text { FIGURAS RELACIONADAS A } \\
\text { IMAGEM }\end{array}$ & $\begin{array}{l}\text { FIGURAS } \\
\text { EXTRAÍDAS DOS } \\
\text { VERSOS }\end{array}$ & $\begin{array}{c}\text { TEMAS } \\
\text { IDENTIFICADOS } \\
\text { COM BASE NAS } \\
\text { FIGURAS }\end{array}$ & $\begin{array}{c}\text { CLASSE } \\
\text { TEMÁTICA }\end{array}$ \\
\hline $\begin{array}{l}\text { *Despojado } \\
\text { *Simplicidade } \\
\text { *Homenageada } \\
\text { *Figura pública } \\
\text { * Escritor } \\
\text { *Político } \\
\text { *Artista } \\
\text { *Poeta }\end{array}$ & $\begin{array}{l}\text { "Ariano, grande mestre } \\
\text { Em arte e simplicidade } \\
\text { Deixou na terra um legado } \\
\text { Fez da nordestinidade } \\
0 \text { mais nobre gesto seu... } \\
\text { Suassuna não morreu, } \\
\text { Modou-se para eternidade" } \\
\text { Ariano Suassuna } \\
\text { Nossa lira nordestina } \\
\text { Carcará e onça parda } \\
\text { Candeeiro e lamparina } \\
\text { Foi o Rei do meu Sertão } \\
\text { Virou Dom Sebastião } \\
\text { Na estrela matutina } \\
\text { "Ariano Suassuna } \\
\text { Foi um grande menestrel } \\
\text { A cultura popular } \\
\text { Defender foi seu papel } \\
\text { A nossa arte mais pura } \\
\text { A música, a arquitetura } \\
\text { Dança, teatro e cordel" } \\
\text { "0 Guerreiro Armorial } \\
\text { Ariano Suassuna } \\
\text { Grande ícone da tribuna } \\
\text { Da Cultura Nacional } \\
\text { É guardião do Portal } \\
\text { Por onde passam milhares } \\
\text { De artistas populares } \\
\text { Que buscam ter afinal } \\
\text { Reconhecimento igual } \\
\text { Aos eruditos, seus pares!" }\end{array}$ & $\begin{array}{l}{ }^{*} \text { Mestre } \\
{ }^{*} \text { Iegado } \\
{ }^{*} \text { nobre } \\
\text { * } \text { Rei } \\
\text { *Estrela } \\
{ }^{*} \text { Menestrel } \\
{ }^{*} \text { Guerreiro } \\
\text { *Ícone } \\
\text { * Reconhecimento }\end{array}$ & $\begin{array}{l}\text { *Homenagem } \\
\text { * Reconhecimento }\end{array}$ & $\begin{array}{c}\text { *Biografias e } \\
\text { personalidades }\end{array}$ \\
\hline
\end{tabular}

Fonte: Elaborado pela autora.

Com base nas informações apresentadas anteriormente, percebeu-se que a xilogravura analisada pode ser indexada com os temas "Homenagem" e "Reconhecimento". Esses temas foram identificados, através da articulação semântica constatada na análise da narrativa visual e da narrativa 
textual e pertencem à classe "Biografias e Personalidades", uma vez que Ariano Suassuna, representado na xilogravura, é uma pessoa que se destacou e se popularizou na memória coletiva.

A Figura 7 apresenta graficamente a classe temática supracitada, identificada por meio dos vocábulos que figurativizam os temas "Homenagem" e "Reconhecimento". Esses vocábulos foram extraídos da análise da narrativa visual e textual, ou seja, da xilogravura e dos versos do folheto.

Figura 7 - Figuras, temas e classe da Xilogravura do folheto "Ariano Suassuna na voz de poetas populares"

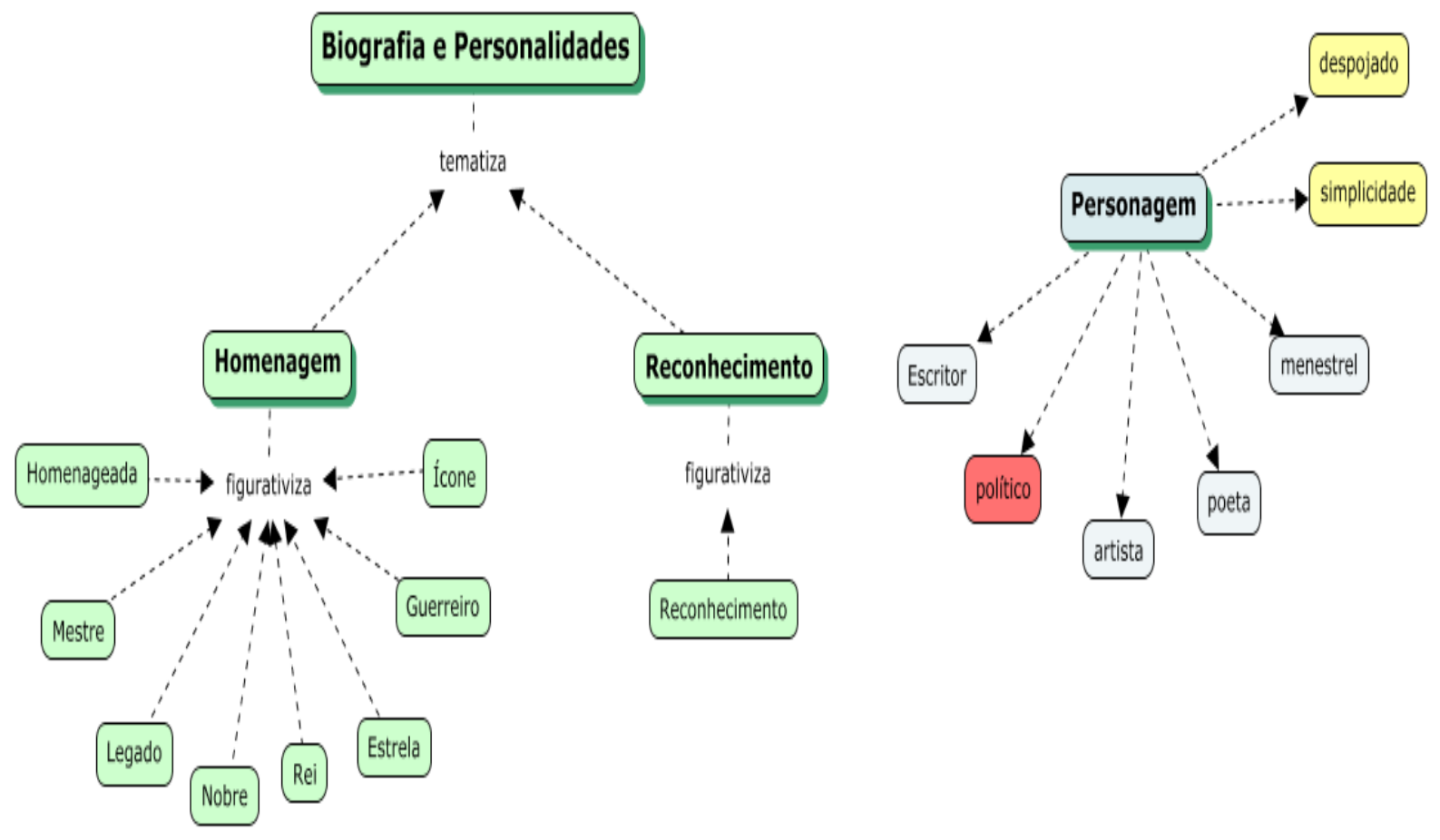

Fonte: Elaborado pela autora.

Dessa forma, os vocábulos "homenageada", "mestre", "legado", "nobre", "rel", "estrela", "guerreiro" e "icone" figurativizam o tema "Homenagem", o que se relaciona com exaltação e respeito pela pessoa representada na imagem. 0 vocábulo "reconhecimento", por sua vez, figurativiza o tema "Reconhecimento", associado ao ato de reconhecer o mérito de alguém. As figuras identificadas na análise da narrativa visual - "escritor", "artista", "poeta", "menestrel", "despojado" e "simplicidade" estão associadas à personalidade da pessoa homenageada, o Ariano Suassuna. Entretanto, identificouse que a figura "político", apontada anteriormente na análise da xilogravura, não possui relação direta com os temas apresentados - o que recai sobre a reflexão de que as pessoas e as suas respectivas 
características nem sempre são identificadas, em primeiro momento, na análise de imagens como as xilogravuras. Por isso a importância da aquisição de informações extrínsecas que apresentem mais referências para o reconhecimento dos conteúdos desses recursos.

Suplementarmente, do lado direito da Figura 7 são apresentados os vocábulos extraídos da análise da xilogravura, associados às características do personagem representado na imagem, os quais também subsidiaram a identificação dos temas e da classe temática supracitada.

\section{Classe "Fenômeno Sobrenatural"}

As xilogravuras também retratam personagens fantásticos, elementos míticos do imaginário popular, coisas malignas ou do mundo espiritual e fenômenos paranormais, como observa-se na Figura a seguir.

Figura 8- Capa do folheto: "A vinda da Besta-fera"

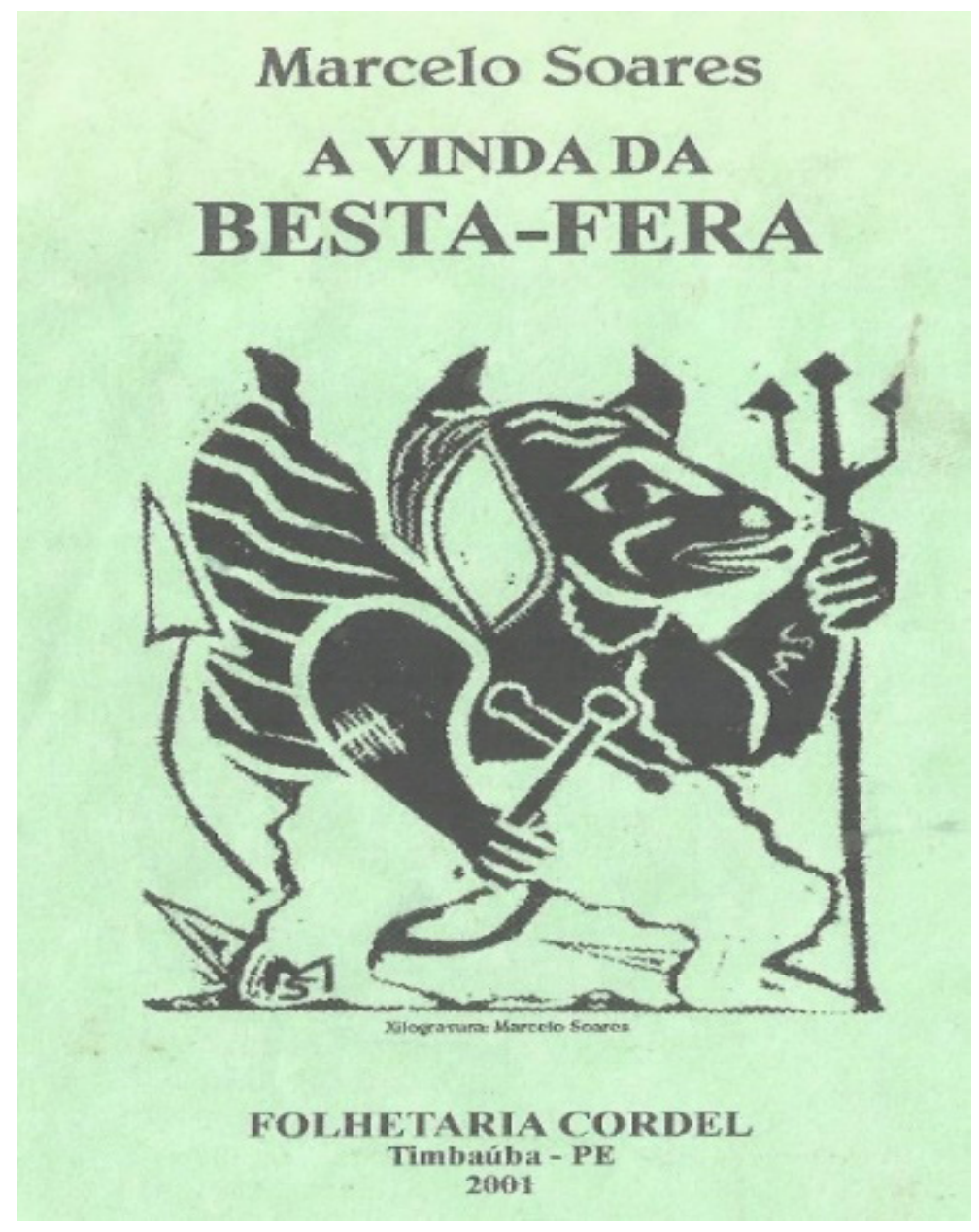

Fonte: Soares (2001). 
Ao analisar essa imagem, notou-se que a mesma representa um personagem sobrenatural com chifres, carregando em sua mão direita uma cruz, símbolo da fé cristã. Em sua mão esquerda tem um tridente, arma que contém cabo alongado com três pontas considerada como símbolo do satanismo. Objetivando apontar essas figuras, o mapa conceitual a seguir apresenta os elementos concretos vislumbrados na narrativa visual.

Figura 9 - Figurativização da Xilogravura do folheto "A vinda da Besta-fera"

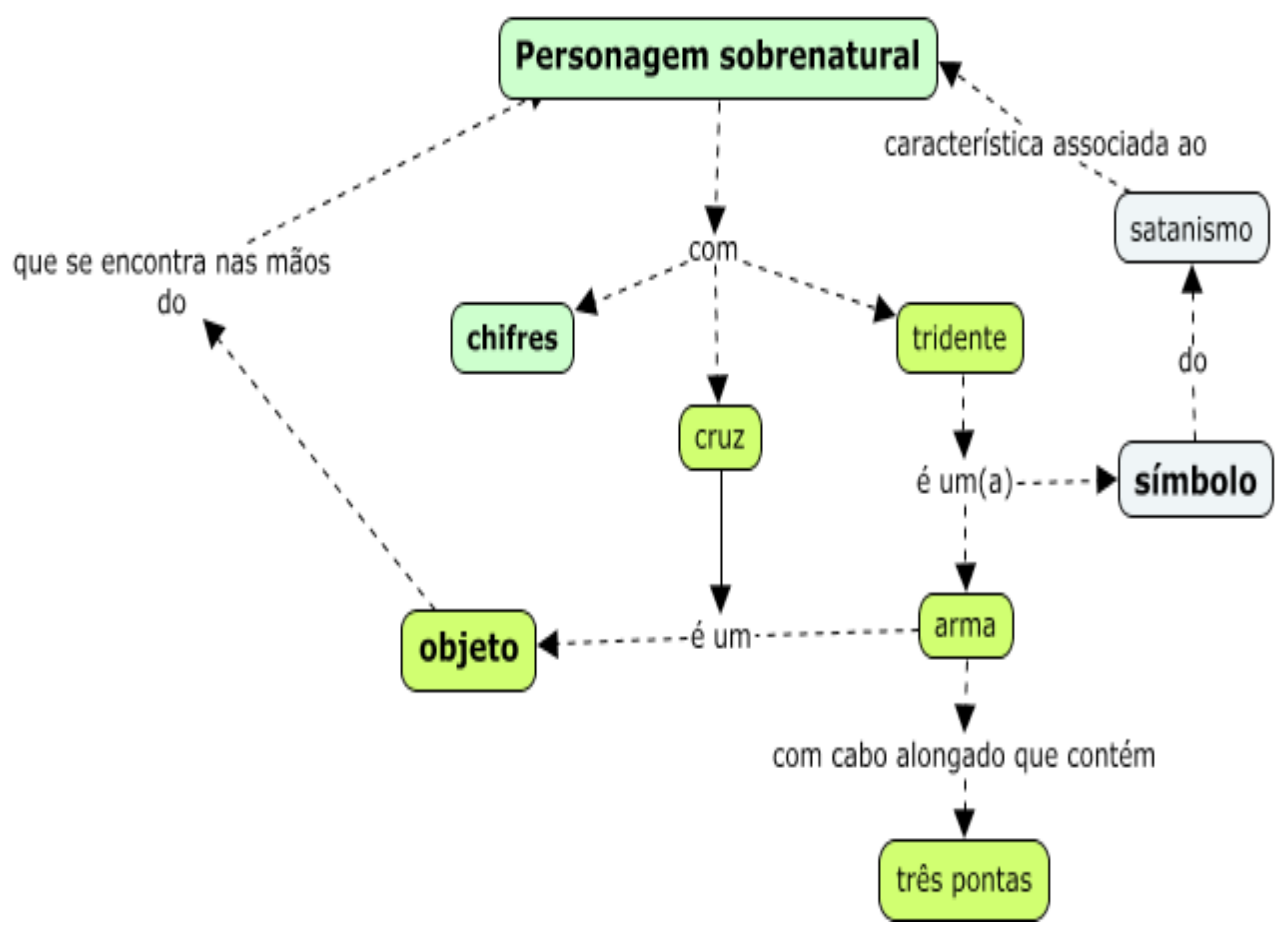

Fonte: Elaborado pela autora.

Após a realização da leitura integral do folheto intitulado "A vinda da Besta-fera", observouse que 0 mesmo se trata da narrativa um pesadelo que o poeta teve ao sonhar com um personagem sobrenatural, denominado de "Besta-fera", anunciando os sinais do fim do mundo. As 30 (trinta) sextilhas do cordel descrevem o poder e os castigos dados por esse ser mítico como forma de repreensão de condutas consideradas socialmente incorretas.

A confluência entre as figuras apresentadas na narrativa visual e na narrativa textual relacionadas ao personagem representado na imagem, é apresentada na Figura 14. 
Figura 10- Articulação semântica entre xilogravura e versos do folheto "A vinda da Besta-fera"

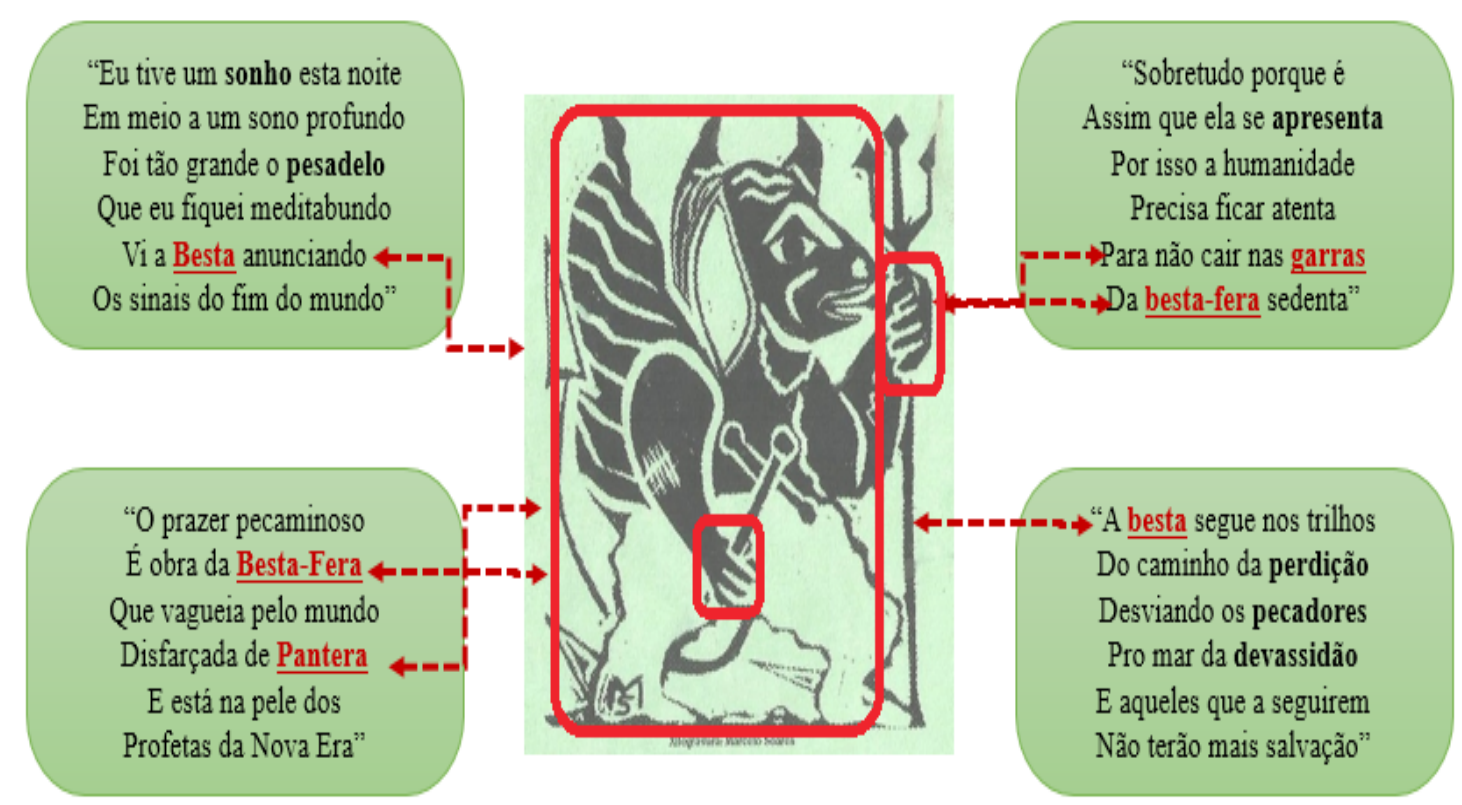

Fonte: Elaborado pela autora.

Ao analisar a ilustração anterior, percebeu-se que os vocábulos "besta", "besta-fera", "pantera"8 correspondem ao personagem sobrenatural representado na xilogravura. 0 vocábulo "garras" está associado à estrutura presente na ponta dos dedos do personagem presente na narrativa visual. Já os vocábulos em negrito estão relacionados com o conteúdo da xilogravura, subsidiando a identificação dos seus temas para fins de indexação.

Nesse entendimento, 0 Quadro 4 objetiva apresentar sinteticamente os temas e a classe temática relacionada à xilogravura, considerando as figuras supracitadas.

8 Termo usado para fazer referência ao gênero de felinos (como tigres, leões, onças, etc.). 
Quadro 4 - Figurativização e Tematização da xilogravura do folheto "A vinda da Besta-fera"

\begin{tabular}{|c|c|c|c|c|}
\hline $\begin{array}{l}\text { FIGURAS } \\
\text { EXTRAÍDAS DA } \\
\text { IMAGEM }\end{array}$ & $\begin{array}{c}\text { VERSOS QUE APRESENTAM } \\
\text { FIGURAS RELACIONADAS À } \\
\text { IMAGEM }\end{array}$ & $\begin{array}{l}\text { FIGURAS } \\
\text { EXTRAÍDAS DOS } \\
\text { VERSOS }\end{array}$ & $\begin{array}{c}\text { TEMAS } \\
\text { IDENTIFICADOS } \\
\text { COM BASE NAS } \\
\text { FIGURAS }\end{array}$ & $\begin{array}{l}\text { CLASSE } \\
\text { TEMÁTICA }\end{array}$ \\
\hline $\begin{array}{c}{ }^{*} \text { Sobrenatural } \\
{ }^{*} \text { Chifres } \\
{ }^{*} \text { Cruz } \\
{ }^{*} \text { tridente } \\
\text { *satanismo }\end{array}$ & $\begin{array}{l}\text { "Eu tive um sonho esta noite } \\
\text { Em meio a um sono profundo } \\
\text { Foi tão grande o pesadelo } \\
\text { Que eu fiquei meditabundo } \\
\text { Vi a Besta anunciando } \\
\text { Os sinais do fim do mundo" } \\
\text { "O prazer pecaminoso } \\
\text { É obra da Besta-Fera } \\
\text { Que vagueia pelo mundo } \\
\text { Disfarçada de Pantera } \\
\text { E está na pele dos } \\
\text { Profetas da Nova Era" } \\
\text { "Sobretudo porque é } \\
\text { Assim que ela se apresenta } \\
\text { Por isso a humanidade } \\
\text { Precisa ficar atenta } \\
\text { Para não cair nas garras } \\
\text { Da besta-fera sedenta" } \\
\text { "A besta segue nos trilhos } \\
\text { Do caminho da perdição } \\
\text { Desviando os pecadores } \\
\text { Pro mar da devassidão } \\
\text { E aqueles que a seguirem } \\
\text { Não terão mais salvação" }\end{array}$ & $\begin{array}{l}\text { *sonho } \\
\text { * pesadelo } \\
\text { *apresenta } \\
\text { * perdição } \\
\text { *pecadores } \\
\text { *devassidão }\end{array}$ & $\begin{array}{l}\text { *Fantasia } \\
\text { *Sobrenatural } \\
\text { *Profanidade } \\
\text { *Assombração }\end{array}$ & $\begin{array}{l}\text { *Fenômeno } \\
\text { sobrenatural }\end{array}$ \\
\hline
\end{tabular}

Fonte: Elaborado pela autora.

Considerando os elementos apresentado no Quadro anterior, observou-se que a xilogravura pode ser indexada com os termos "Fantasia", "Sobrenatural", "Profanidade" e "Assombração". Esses temas são identificados mediante a articulação semântica constatada na análise da imagem e da narrativa textual. Seguindo essa linha de raciocínio, é possível dizer que essa imagem faz parte da classe temática "Fenômeno sobrenatural", uma vez que ilustra a Besta-fera - personagem sobrenatural e elemento mítico do imaginário popular.

A Figura 11 apresenta, de maneira detalhada, o resultado do processo de figurativização e tematização da xilogravura. 
Figura 11 - Figuras, temas e classes da xilogravura do folheto "A vinda da Besta-fera"

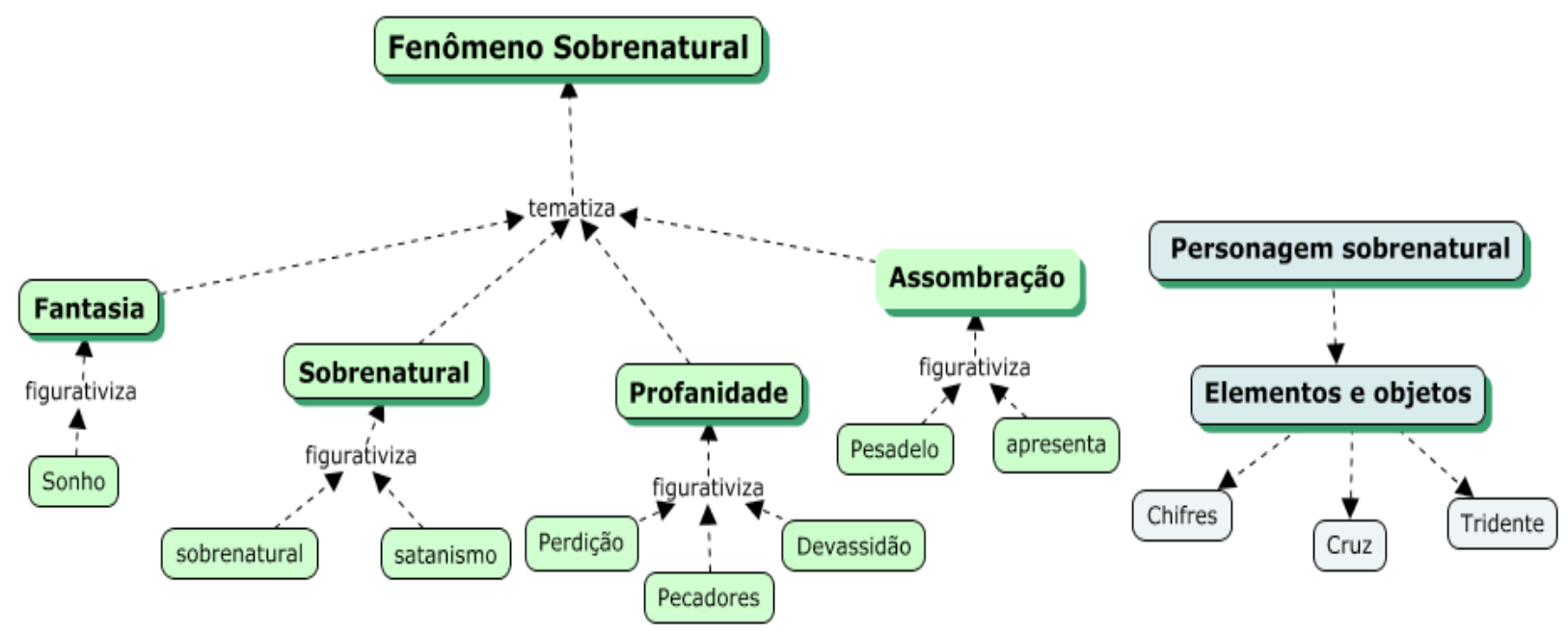

Fonte: Elaborado pela autora.

Diante disso, observou-se que o vocábulo "sonho" figurativiza o tema "Fantasia" - faculdade humana de reprodução de imagens mentais acerca de fatos ou fenômenos sobrenaturais. Os vocábulos "sobrenatural" e "satanismo", por sua vez, figurativizam o tema "Sobrenatural", caracterizando personagens ou seres que transcendem as forças da natureza humana, especificamente aqueles que representam um universo, além do planeta terra. Os vocábulos "perdição", "pecadores" e "devassidão" figurativizam o tema "profanidade", caracterizando ações ou práticas profanas que transgridem as regras sagradas. Por outro lado, os vocábulos "pesadelo" e "assombração" figurativizam o tema "Assombração", designando os objetos fantásticos ou vultos de seres incorpóreos que habitam ou transitam em determinados ambientes, com o intuito de amedrontar pessoas.

Além disso, no processo de análise da xilogravura, foram identificadas as figuras presentes na narrativa visual, associadas ao personagem representado na xilogravura, são elas: "personagem sobrenaturaf", "chifres", "cruz" e "tridente". Percebeu-se que esses vocábulos dizem respeito às características e símbolos referentes ao personagem ilustrado e também subsidiam o processo de tematização da imagem.

\section{Classe "Morte"}

0 artista também elabora xilogravuras que tratam sobre acontecimentos causadores de tristeza ou de interrupção da vida de uma pessoa ou organismo, como observa-se na Figura a seguir. 
Figura 12- Capa do folheto: "Eu vi, meninos. Eu vi. 0 Golpe militar e civil 1964"

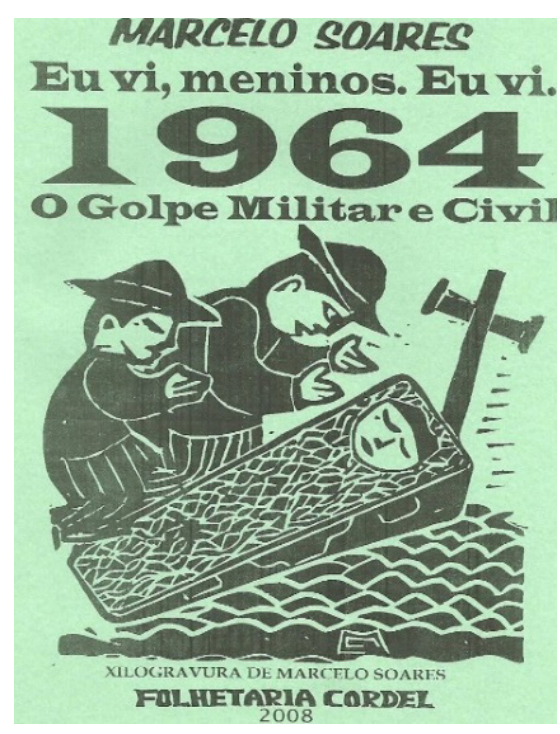

Fonte: Soares (2008).

Nota-se que a xilogravura retrata três pessoas. Dois deles se encontram ajoelhados com as mãos direcionadas para o caixão com um corpo de uma pessoa dentro, aparentemente os dois personagens estão consternados com a morte do ente querido. No plano direito da imagem, próximo ao caixão, contém uma cruz - 0 que simboliza a morte.

0 mapa conceitual a seguir apresenta a síntese dos elementos destacados anteriormente, os quais se constituem como as figuras da imagem analisada.

Figura 13 - Figurativização da xilogravura do folheto "Eu vi, meninos. Eu vi. 0 Golpe militar e civil 1964"

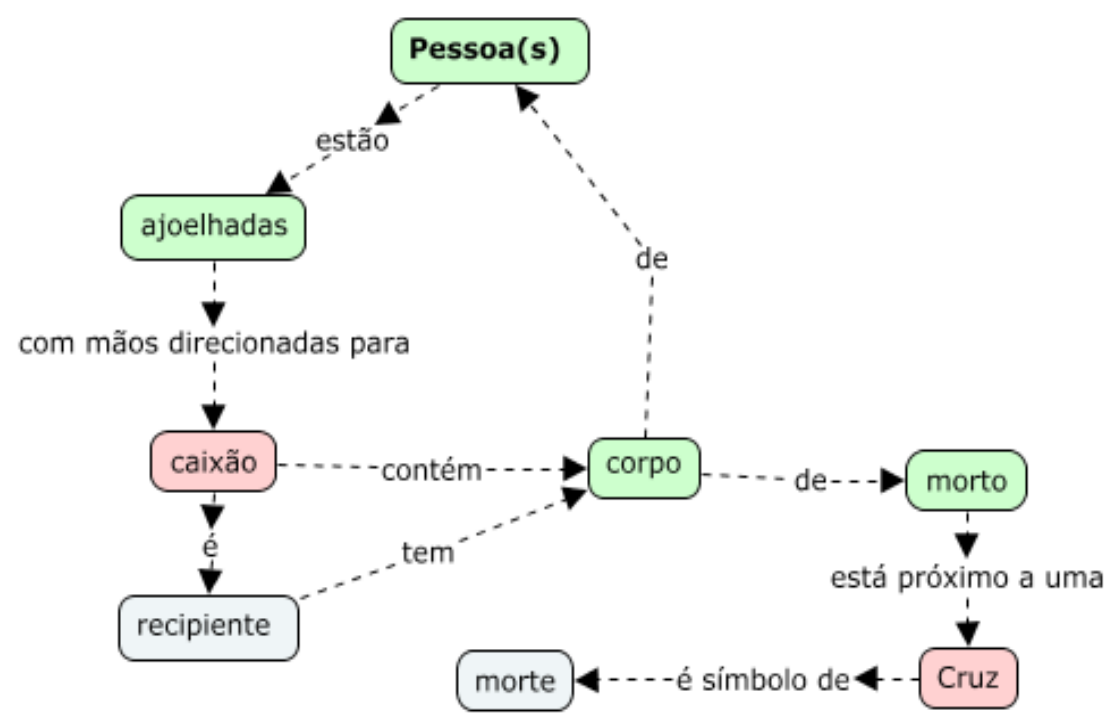

Fonte: Elaborado pela autora. 
Após a leitura integral do folheto percebeu-se que o poeta relata em 24 (vinte e quatro) septilhas, aspectos relativos ao golpe civil e militar no Brasil em 1964, sobretudo sobre as mortes causadas em razão do regime militar - regime opressivo e totalitário mantido através das forças brutas, cometendo maiores atrocidades contra aqueles que se opunham a essa lógica (como estudantes, intelectuais, engajados políticos, etc.).

Nesse limiar, a seguir é constatada a articulação semântica entre a xilogravura e os versos do folheto.

Figura 14 - Articulação semântica entre xilogravura e versos do folheto "Eu vi, meninos. Eu vi. 0 Golpe militar e civil 1964"

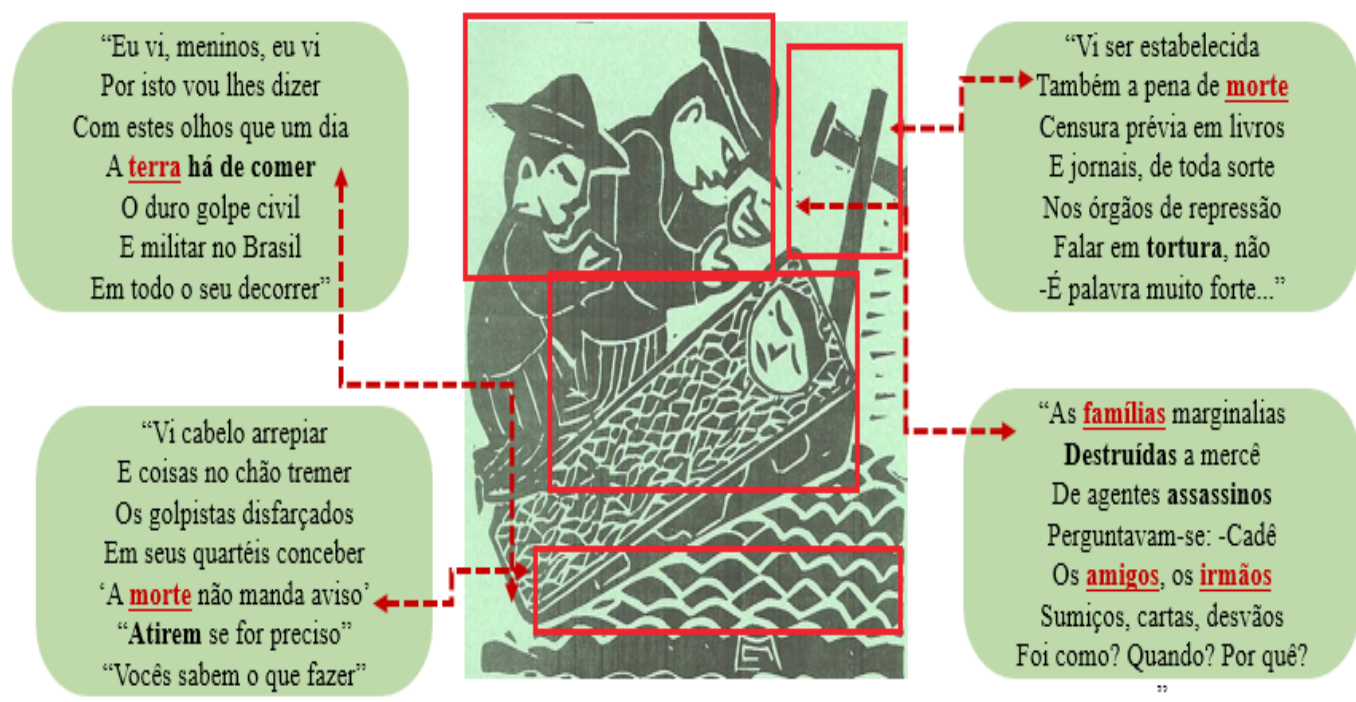

Fonte: Elaborado pela autora.

Seguindo essa linha de raciocínio, percebeu-se que os vocábulos "terra", "morte", "famílias", "amigos" e "irmãos" pode estar associado aos personagens e elementos retratados na xilogravura. Notou-se ainda que a expressão "terra há de comer" e os vocábulos "atirem", "tortura", "destruídas" e "assassinos" foram extraídos dos versos do folheto e estão relacionados direta e indiretamente ao conteúdo da imagem em questão, os quais subsidiam o processo de tematização desse recurso imagético.

0 Quadro 5 expõe as figuras apresentadas nas análises da narrativa visual e textual. Além disso, apresenta os temas identificados com base na confluência dessas figuras, bem como elenca a classe temática que a xilogravura está associada. 
Quadro 5 - Figurativização e Tematização da xilogravura do folheto "Eu vi, meninos. Eu vi. 0 Golpe militar e civil 1964"

\begin{tabular}{|c|c|c|c|c|}
\hline $\begin{array}{l}\text { FIGURAS } \\
\text { EXTRAÍDAS DA } \\
\text { IMAGEM }\end{array}$ & $\begin{array}{l}\text { VERSOS QUE APRESENTAM } \\
\text { FIGURAS RELACIONADAS À } \\
\text { IMAGEM }\end{array}$ & $\begin{array}{l}\text { FIGURAS } \\
\text { EXTRAÍDAS DOS } \\
\text { VERSOS }\end{array}$ & $\begin{array}{c}\text { TEMAS } \\
\text { IDENTIFICADOS } \\
\text { COM BASE NAS } \\
\text { FIGURAS }\end{array}$ & $\begin{array}{l}\text { CLASSE } \\
\text { TEMÁTICA }\end{array}$ \\
\hline $\begin{array}{l}\text { *Pessoas } \\
\text { *ajoelhadas } \\
{ }^{*} \text { caixão } \\
{ }^{*} \text { cruz }\end{array}$ & $\begin{array}{l}\text { "Eu vi, meninos, eu vi } \\
\text { Por isto vou Ihes dizer } \\
\text { Com estes olhos que um dia } \\
\text { A terra há de comer } \\
\text { O duro golpe civil } \\
\text { E militar no Brasil } \\
\text { Em todo o seu decorrer" } \\
\text { "Vi cabelo arrepiar } \\
\text { E coisas no chão tremer } \\
\text { Os golpistas disfarçados } \\
\text { Em seus quartéis conceber } \\
\text { 'A morte não manda aviso' } \\
\text { "Atirem se for preciso" } \\
\text { "Vocês sabem o que fazer" } \\
\text { "Vi ser estabelecida } \\
\text { Também a pena de morte } \\
\text { Censura prévia em livros } \\
\text { E jornais, de toda sorte } \\
\text { Nos órgãos de repressão } \\
\text { Falar em tortura, não } \\
\text {-É palavra muito forte..." } \\
\text { "As famílias marginalias } \\
\text { Destruídas a mercê } \\
\text { De agentes assassinos } \\
\text { Perguntavam-se: -Cadê } \\
\text { Os amigos, os irmãos } \\
\text { Sumiços, cartas, desvãos } \\
\text { Foi como? Quando? Por quê? }\end{array}$ & $\begin{array}{l}\text { *"terra há de } \\
\text { comer" } \\
\text { *morte } \\
\text { *atirem } \\
\text { *tortura } \\
\text { *destruídas } \\
\text { *assassinos }\end{array}$ & $\begin{array}{l}\text { * Morte } \\
\text { *Assassinato } \\
\text { *Sofrimento }\end{array}$ & ${ }^{\star}$ Morte \\
\hline
\end{tabular}

Fonte: Elaborado pela autora.

Com base na confluência das figuras identificadas, notou-se que a xilogravura pode ser indexada pelos temas "morte", "assassinato" e "sofrimento". Esses temas pertencem à classe temática "Morte", designando o término da vida de uma pessoa ou organismo, assim como o seu estado após o evento.

A Figura 15 expões os vocábulos e expressões que figurativizam esses temas e essa classe temática. 
Figura 15 - Figuras, temas e classes da xilogravura do folheto "Eu vi, meninos. Eu vi. 0 Golpe militar e civil 1964"

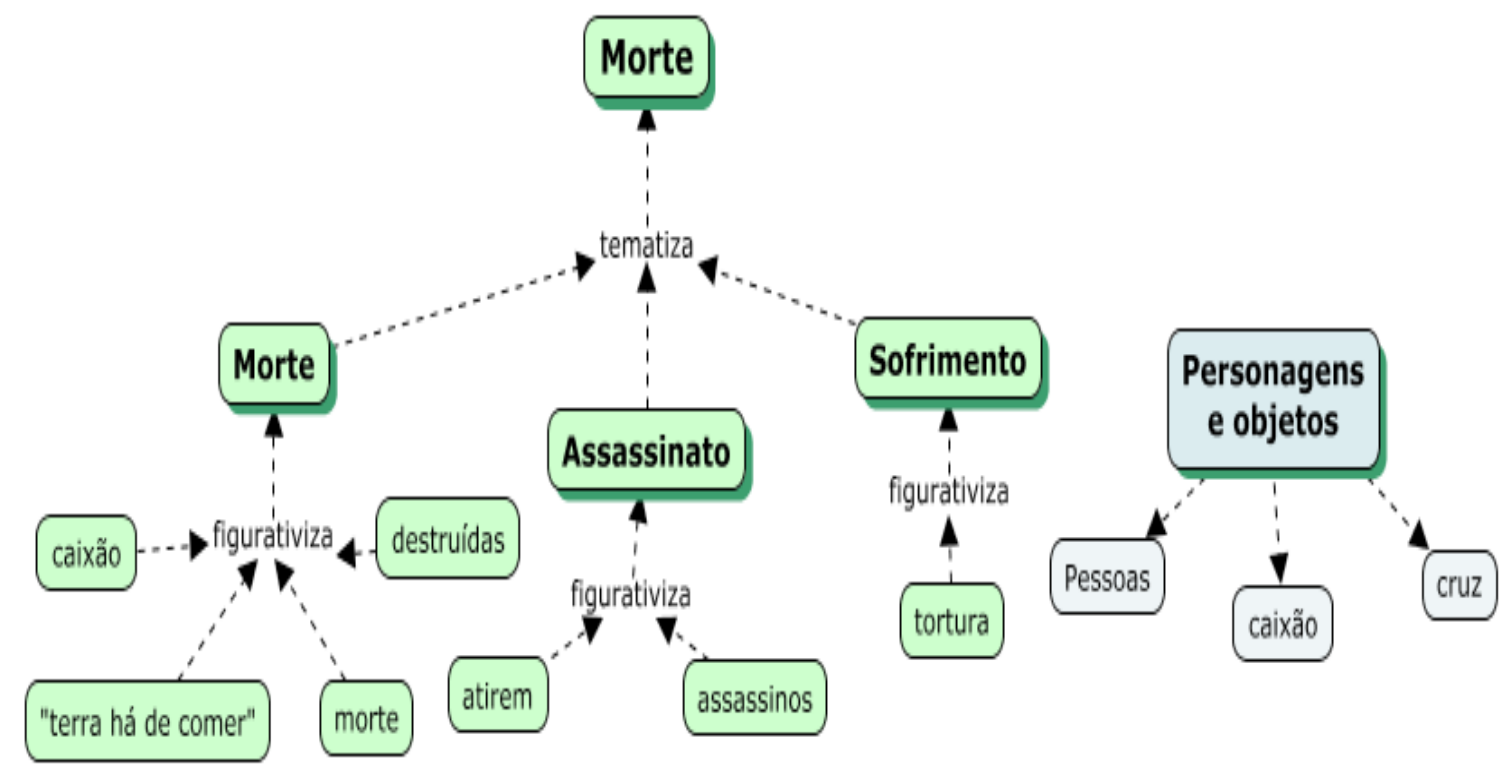

Fonte: Elaborado pela autora.

Destarte, os vocábulos "caixão", "morte", "destruídas" e a expressão "terra há de comer" figurativizam o tema "morte”, designando a interrupção definitiva da vida do homem enquanto matéria física. Os vocábulos "atirem" e "assassinos" figurativizam o tema "assassinato", caracterizando um ato intencional de tirar a vida de outra pessoa, de maneira ilegal. 0 vocábulo "tortura", por sua vez, figurativiza o tema "sofrimento", sensação consciente ou inconsciente de dor, mal-estar ou infelicidade. Do lado direito da ilustração apresentada anteriormente também são apresentados os personagens e objetos retratados na imagem, os quais contribuem para o processo de sua indexação.

Com base nesse entendimento, embora o folheto de cordel descreva aspectos relativos a um fato histórico, a ditadura militar de 1964, foi possível perceber que o conteúdo da xilogravura não corresponde diretamente à classe temática "História". Isso se deve ao fato de que a imagem representa o conteúdo principal do folheto, o qual está associado às mortes, torturas, sofrimentos provocados por esse evento que ocorreu no Brasil. Nessa perspectiva, verificou-se que a análise de imagens como as xilogravuras deve estar pautada, primeiramente, na narrativa visual e na articulação semântica da mesma com as fontes adicionais -nesse caso os títulos e os versos do folheto- objetivando tornar a indexação mais próxima possível de atender os parâmetros conceituais da xilogravura. 


\section{Classe "Político e Social"}

Além de carregar consigo o caráter artístico, poético e literário, as xilogravuras de cordel também representam elementos políticos e sociais, como classes sociais, desigualdades sociais, luta de classes, inclusão social, entre outros. Na figura a seguir, observa-se a xilogravura do folheto intitulado "Nosso país precisa fazer reforma agrária":

Figura 16 - Capa do folheto "Nosso país precisa fazer Reforma Agrária"

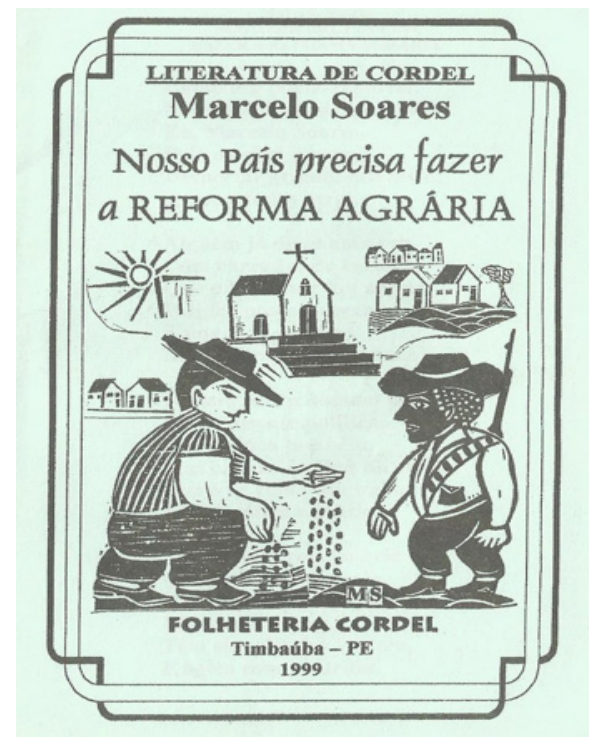

Fonte: Soares (1999).

A xilogravura apresentada é composta por diversos elementos. Em primeiro plano a figura de dois homens. Do lado esquerdo, a ilustração de um homem lançando sementes na terra, o que pode ser comparado a imagem do camponês realizando o plantio para que a planta germine, cresça e dê frutos. Do lado direito, é possível observar a figura de um homem com arma suspensa pela bandoleira ao ombro, posicionado de frente para o camponês. Na narrativa visual, a ilustração do homem armado pode estar associada à imagem de um policial ou de um proprietário de terras. Ou seja, na atividade de análise de imagens, inicialmente podem surgir dúvidas por parte de quem analisa a xilogravura, em relação aos personagens e elementos que se encontram representados.

Adicionalmente, no plano posterior da xilogravura, foram verificados traços urbanos por meio da ilustração de casas e de uma igreja posicionada no centro - os quais podem estar associados ao fato de que, nas cidades brasileiras, as igrejas estão localizadas no centro da comunidade. 
0 mapa conceitual a seguir elenca as figuras (personagens, objetos, ação e elementos) reconhecidas na xilogravura mediante a análise da narrativa visual presente nesse recurso imagético.

Figura 17 - Figurativização da xilogravura do folheto "Nosso país precisa fazer Reforma Agrária"

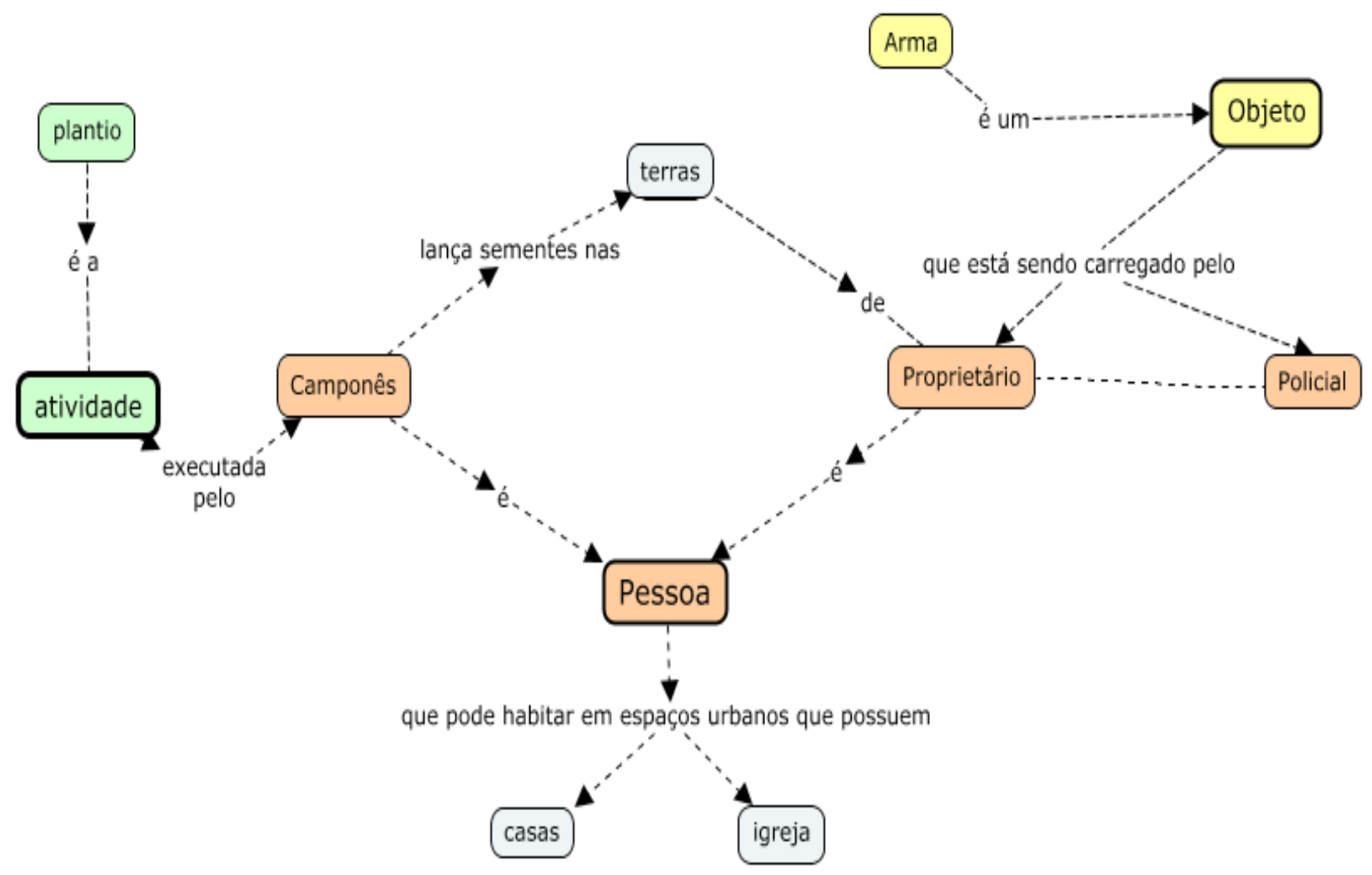

Fonte: Elaborado pela autora.

Ao ler integralmente 0 folheto em que a xilogravura se encontra ilustrada, verificou-se que 0 mesmo discorre sobre a precariedade da situação do homem do campo e a necessidade de realização da reforma agrária no Brasil. 0 cordel composto por 32 (trinta e duas) sextilhas aponta também questões de violência por parte dos latifundiários e do problema agrário brasileiro, enfatizando que as diferenças estão relacionadas à configuração social e política.

Nesse limiar, a Figura a seguir apresenta a imbricação entre as figuras apresentadas na xilogravura e nos versos do folheto, as quais são relativas à atividade, e aos personagens representados na imagem. 
Figura 18 - Articulação semântica entre xilogravura e versos do folheto "Nosso país precisa fazer a

\section{Reforma Agrária"}

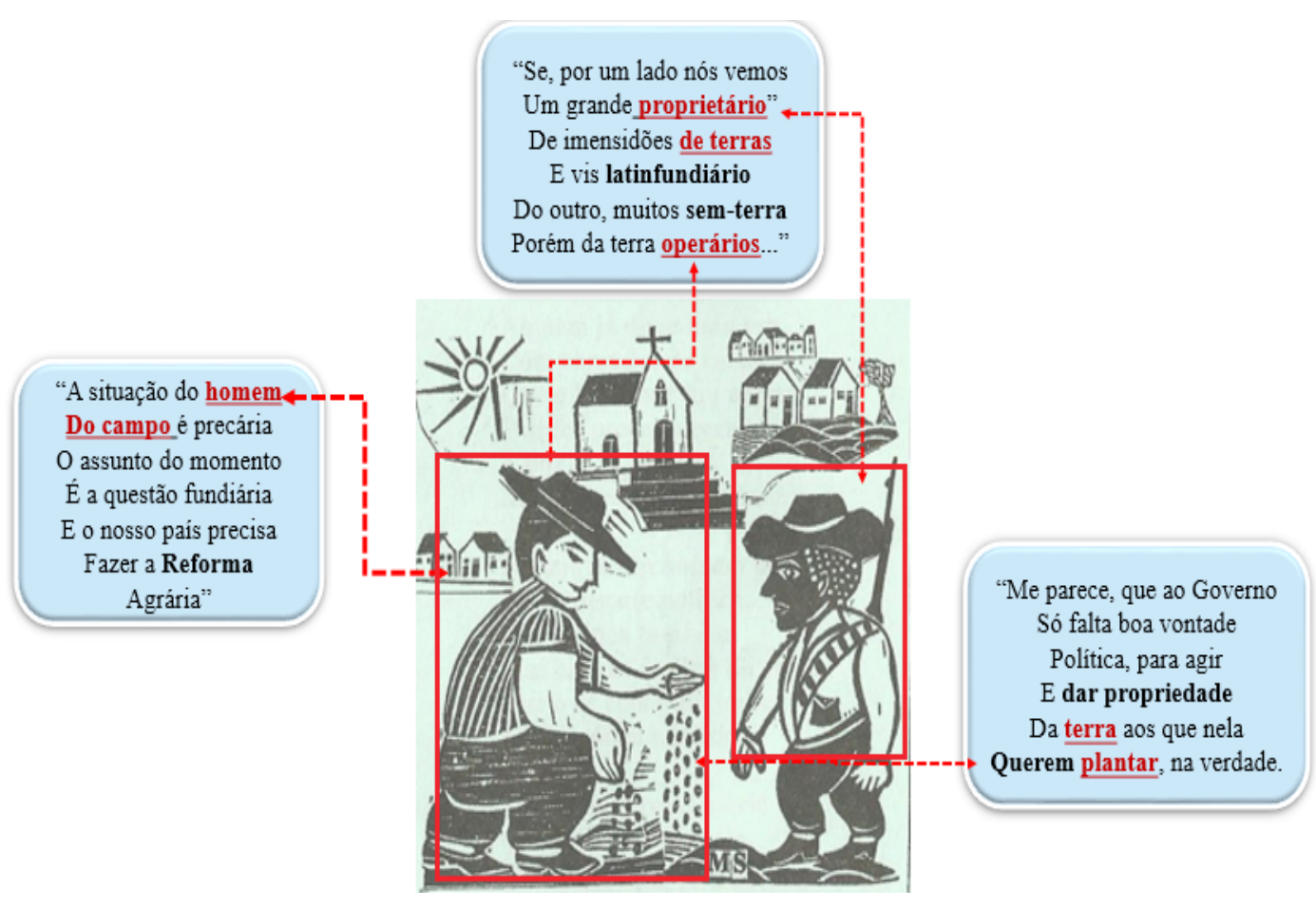

Fonte: Elaborado pela autora.

Com base na análise da ilustração, verificou-se que 0 vocábulo "operário" e as expressões "proprietário de terras" e "homem do campo" remetem aos personagens representados na xilogravura. 0 vocábulo "plantar" está associado à ação retratada na imagem. 0 vocábulo "terra", por sua vez, está associado à superfície representada na imagem. Por outro lado, os vocábulos destacados em negrito subsidiam a identificação do tema da xilogravura, embora tenham sido também extraídos dos versos do folheto analisado.

0 Quadro 6 apresenta, de maneira sintética, os resultados do processo de figurativização e tematização dessa xilogravura. 
Quadro 6- Figurativização e Tematização da xilogravura do folheto "Nosso país precisa fazer a Reforma Agrária"

\begin{tabular}{|c|c|c|c|c|}
\hline $\begin{array}{l}\text { FIGURAS } \\
\text { EXTRAÍDAS DA } \\
\text { IMAGEM }\end{array}$ & $\begin{array}{c}\text { VERSOS QUE APRESENTAM } \\
\text { FIGURAS RELACIONADAS À } \\
\text { IMAGEM }\end{array}$ & $\begin{array}{c}\text { FIGURAS EXTRAÍDAS } \\
\text { DOS VERSOS }\end{array}$ & $\begin{array}{c}\text { TEMAS } \\
\text { IDENTIFICADOS } \\
\text { COM BASE NAS } \\
\text { FIGURAS }\end{array}$ & $\begin{array}{l}\text { CLASSE } \\
\text { TEMÁTICA }\end{array}$ \\
\hline $\begin{array}{c}\text { *Camponês } \\
\text { *arma } \\
\text { *Proprietário de } \\
\text { terras } \\
{ }^{*} \text { Policial } \\
\text { *Casas } \\
\text { *Igreja }\end{array}$ & $\begin{array}{l}\text { "A situação do homem } \\
\text { Do campo é muito precária } \\
0 \text { assunto do momento } \\
\text { É a questão fundiária } \\
\text { E o nosso país precisa } \\
\text { Fazer a Reforma Agrária" } \\
\text { Se, por um lado nós vemos } \\
\text { O grande proprietário } \\
\text { De imensidões de terras } \\
\text { E vis latifundiários } \\
\text { Do outro, muitos sem-terra, } \\
\text { Porém da terra operários } \\
\text { Me parece, que ao Governo } \\
\text { Só falta boa vontade } \\
\text { Política, para agir } \\
\text { E dar a propriedade } \\
\text { Da terra aos que nela } \\
\text { Querem plantar, na verdade. }\end{array}$ & $\begin{array}{l}\text { *Homem do campo } \\
\text { *Reforma } \\
\text { *Proprietário de terras } \\
\text { * Iatifundiários } \\
\text { *Sem-Terra } \\
\text { *Operários } \\
\text { * dar a propriedade } \\
\text { * querem plantar }\end{array}$ & $\begin{array}{l}\text { *Classe social } \\
\text { *Armamento } \\
\text { *Transformação }\end{array}$ & $\begin{array}{c}\text { *Político e } \\
\text { Social }\end{array}$ \\
\hline
\end{tabular}

Fonte: Elaborado pela autora.

Nessa perspectiva, a partir da análise da narrativa visual e textual notou-se que o conteúdo da xilogravura pode ser representado pelos temas "classe social", "armamento" e "transformação". Dessa forma, a xilogravura pertence à classe temática "Político e social", uma vez que essa imagem contempla elementos associados à Reforma Agrária, reorganização da estrutura fundiária pelo governo no intuito de viabilizar a redistribuição de terras para a realização da sua função social. A Reforma Agrária diz respeito a uma questão política e social que não está apenas associada aos trabalhadores rurais Sem Terras, sendo também de grande importância para toda a sociedade brasileira. 
A seguir são apresentados os vocábulos que figurativizam os temas supracitados e que, por sua vez, pertencem à classe temática "Político e Social".

Figura 19 - Figuras, temas e classe da xilogravura do folheto "Nosso país precisa fazer a Reforma Agrária"

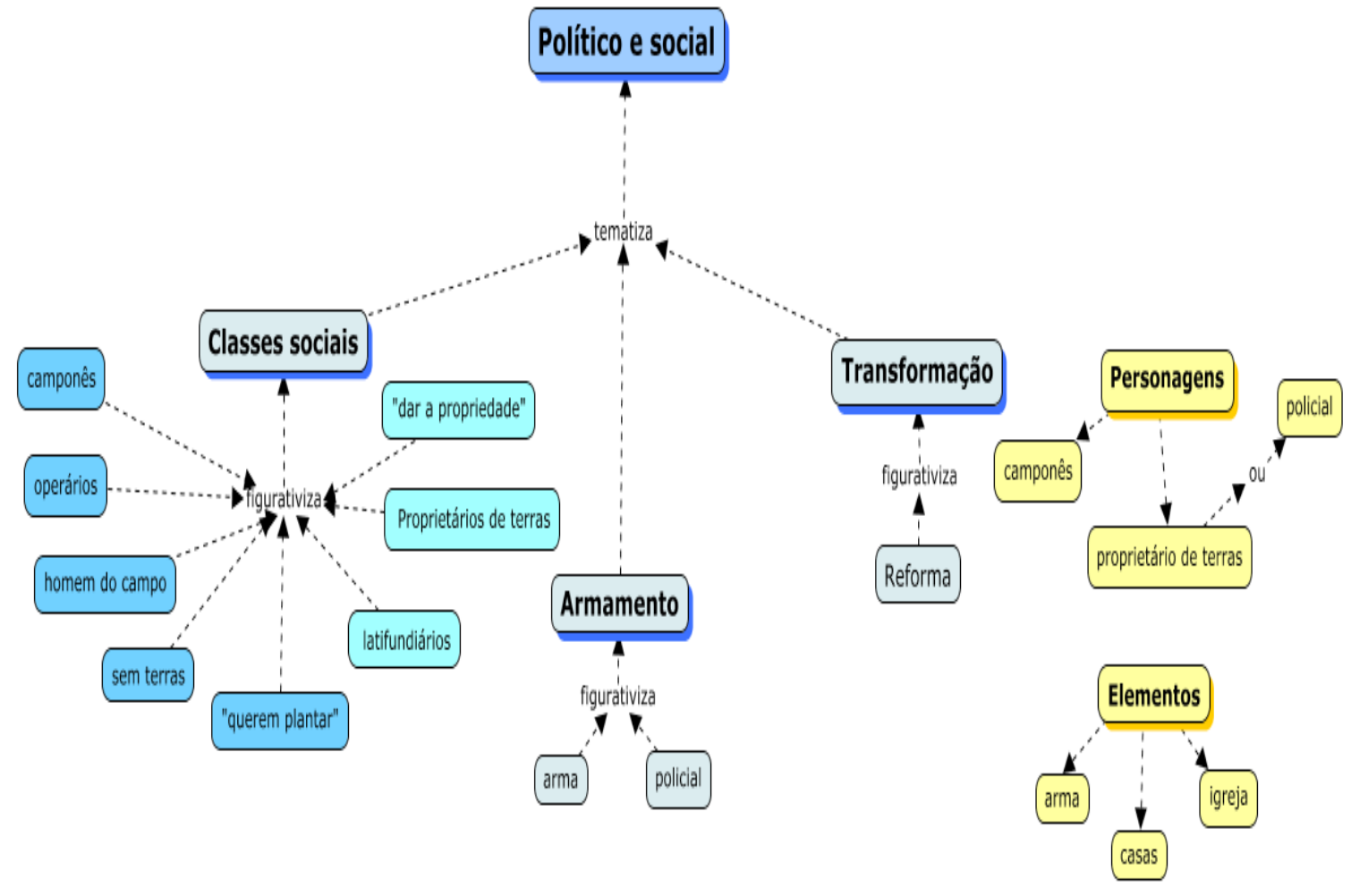

Fonte: Elaborado pela autora.

Os vocábulos "camponês", "operários", "latifundiários" e as expressões "homem do campo", "sem terras", "querem plantar", "proprietários de terras" e "dar a propriedade" figurativizam 0 tema "classes sociais", pois a imagem representa duas pessoas que fazem parte de grupos diferentes - os latifundiários (proprietários de terras) e o proletariado (classe operária) - cujos padrões culturais, políticos e econômicos são divergentes. Já os vocábulos "arma" e "policial" figurativizam o tema "armamento", ato ou efeito de armar. 0 vocábulo "reforma" figurativiza o tema "transformação", que diz respeito a qualquer modificação no estado de um sistema como a reforma agrária, por exemplo. Do lado direito da ilustração apresentada anteriormente, estão dispostos os vocábulos e a expressão extraída da análise da narrativa visual, relacionados aos personagens ("camponês", "proprietário de terras", "policial”) e elementos retratados na xilogravura ("arma", "casas" e "igreja”). Esses vocábulos também subsidiaram a identificação dos temas supracitados que pertencem à classe temática "político e social". 
Ao analisar essa xilogravura sem a consulta de informações adicionais e ao ver a imagem de um camponês realizando o plantio, o profissional indexador pode em primeiro momento associar a xilogravura à classe temática "Agricultura". Outro fator que pode implicar na dispersão interpretativa nessa situação, diz respeito à dificuldade de estabelecer conexões em relação ao conjunto de elementos retratados na imagem em questão, os quais estão relacionados à reforma agrária. Por isso a importância da análise do conjunto de elementos associados à imagem, bem como da articulação sintagmática entre a imagem e os versos do folheto.

\section{CONSIDERAÇÕES FINAIS}

A representação no contexto da Ciência da Informação conquista espaço não apenas como uma operação pragmática, mas se amplia como campo que abrange estudos teóricos e aplicados que objetivam tornar o uso e a apropriação do conhecimento produzido, considerando questões éticas e socioculturais no intuito de tornar os registros informacionais disponíveis à sociedade. Para tanto, direciona os seus processos, produtos e instrumentos na informação registrada (no objeto informacional, item informacional, recurso informacional), independente de o suporte ser analógico ou digital.

As xilogravuras, enquanto textos não verbais, apresentam elementos concretos (figuras) que retratam o imaginário, mundo construído, de seus artistas mediante a representação de pessoas, anjos, fadas, demônios, príncipes, princesas, etc. - os quais constituem como simulação da realidade construída. Essas imagens também apresentam elementos abstratos (temas) que condensam as narrativas de cordéis por meio de imagens que retratam temas como vida, amor, fidelidade, traição, educação, crimes, julgamentos, etc. - multiplicando os sentidos e os significados associados ao cotidiano e a vida social.

Nas análises realizadas nesta pesquisa foi constatada a articulação semântica das ações, elementos ou objetos representados nas xilogravuras com os discursos apresentados nos versos dos folhetos, o que está associado ao fato de que as xilogravuras em folhetos de cordel visam a condensação das narrativas textuais mediante as suas funções mnemônicas, bem como multiplicam sentidos e significados a partir de suas funções metafóricas.

Sendo assim, metodologia proposta nesta pesquisa considera que a análise de imagens deve estar pautada, primeiramente, na narrativa visual e na articulação semântica da mesma com o conteúdo 
das fontes adicionais relacionadas a esses recursos (como o título, legendas, versos do folheto, tags atribuídas pelos usuários em um dado sistema, etc.), contemplando os procedimentos de figurativização e tematização da Semântica Discursiva.

Face ao exposto, acredita-se que os objetivos deste estudo foram alcançados, uma vez que nas análises realizadas foram evidenciadas as potencialidades da Semântica Discursiva, mediante os processos de figurativização e tematização, para a indexação de recursos imagéticos altamente subjetivos como as xilogravuras. Os seus contributos resultam em uma nova maneira de extrair os conteúdos de imagens, trazendo como diferencial a redução do nível de subjetividade, tornando a indexação mais próxima possível de atender os parâmetros conceituais das xilogravuras enquanto recursos imagéticos que retratam a realidade e 0 imaginário popular.

Com base nessa perspectiva, verifica-se que a proposta apresentada nesta pesquisa centra-se na representação temática e podem ser implementadas ou aperfeiçoadas para a indexação de outros tipos de imagens, sem necessariamente ser as xilogravuras. Essas ideias podem servir de referência para a construção e desenvolvimento de um módulo de indexação para sistemas ou coleções de recursos imagéticos como fotografias e obras artístico-pictóricas, por exemplo. Para tanto, torna-se necessária a formação de uma equipe composta por profissionais da informação também capacitados para a execução das tarefas sugeridas anteriormente.

A criação de uma política de indexação em consonância com as especificidades e singularidades das imagens a serem trabalhadas, consiste em um fator importante para a execução de um trabalho colaborativo eficiente em bancos de imagens e sistemas de recuperação da informação. Ademais, ferramentas colaborativas também precisam ser criadas e implementadas para fins de indexação e recuperação desses recursos imagéticos com base nas potencialidades da Semântica Discursiva e da Folksonomia, assim como proposto na pesquisa de Santos (2019).

Nesse limiar, espera-se que esta pesquisa possa contribuir para a produção significativa de metadados semânticos na indexação de imagens, bem como para a organização de acervos imagéticos que contemplam xilogravuras enquanto recursos a serem recuperados e acessados pelos usuários.

\section{REFERÊNCIAS}

AGUIAR, I. M. et al. Literatura de cordel digitalizada: preservação e disseminação do acervo da Biblioteca Central da Universidade Estadual de Londrina. In: SEMINÁRIO NACIONAL DE BIBLIOTECAS UNIVERSITÁRIAS (SNBU), 15., 2008, São Paulo. Anais [...] São Paulo: UNICAMP, 2008, p.1-8. 
ALBUQUERQUE, M. E. B. C. Literatura popular de Cordel: dos ciclos temáticos à classificação bibliográfica. 2011. Tese (Doutorado em Letras) - Universidade Federal da Paraíba, João Pessoa, 2011. Disponível em: https://repositorio.ufpb.br/jspui/handle/tede/6183. Acesso em: 21 mar. 2020.

ALBUQUERQUE, M. E. B. C. et al. Na memória da tradição: fontes de informação em literatura de cordel. João Pessoa: Editora da UFPB, 2016.

ANTONIO, D. M. 0 Percurso Gerativo de Sentido aplicado à análise documental de textos narrativos de ficção: perspectivas de utilização em bibliotecas universitárias. 2008. Dissertação (Mestrado em Ciência da Informação) - Faculdade de Filosofia e Ciências, Universidade Estadual Paulista, 2008.

BRASIL. Comunicação Para Efeito de Registro do Bem Cultural de Natureza Imaterial Denominado "Literatura de Cordel" Como Patrimônio Cultural do Brasil. Diário Oficial da União. Brasília, DF. 20 ago. 2018. Seção3, p. 12. Disponível em: https://www.jusbrasil.com.br/diarios/204544074/dousecao-3-20-08-2018-pg-12. Acesso em: 21 mar. 2020.

BARBALHO, C. R. S. Fazer semiótico: subsídios para exame do espaço concreto. Enc. Bibli: R. Eletr. Bibliotecon. Ci. Inf., Florianópolis, 2 número esp., p. 79-96, 2006.

BARTHES, R. A câmara clara: nota sobre fotografia. Tradução Júlio Castañon Guimarães. Rio de Janeiro: Nova Fronteira, 1984.

BARTHES, R. "A retórica da imagem”, In: BARTHES, R. 0 óbvio e o obtuso. Rio de Janeiro: Nova Fronteira,1990. p.50-68. (Coleção Obras de Roland Barthes).

BEGHTOL, C. Ehtical decision-making for knowledge representation and organization systems for global use. Journal of the American Society for Information Science and Technology, New York, v. 56, n.9, p.903-912, 2005. Disponível em: https://onlinelibrary.wiley.com/doi/abs/10.1002/asi.20184. Acesso em: 21 mar. 2020.

CARVALHO, G. de. A xilogravura de Juazeiro do Norte. Fortaleza: IPHAN, 2014.

FEBVRE, L.; MARTIN, H. 0 aparecimento do livro. São Paulo: UNESP, 1992.

FIORIN, J. L. Elementos de análise do discurso. São Paulo: Contexto, 1999.

FIORIN, J.; SAVIOLI, F. Para entender o texto. São Paulo: Ática. 2003.

HALL, S. Representation: cultural representations and signifying practis. London: Sage, 1997.

LICARIÃO, V. Xilogravura [Folheto]/V. Licarião. [S.I.:S.n.], [19--?]. 8p.

MACHADO, V. F.; ALBUQUERQUE, A. C. de. A representação temática de xilogravura: o processo de indexação da coleção Paulo Menten. Revista ACB: Biblioteconomia em Santa Catarina, Florianópolis, v.21, n.3, p.856-873, ago./nov. 2016.

MANINI, M. P. Análise documentária de fotografias: um referencial de leitura de imagens fotográficas para fins documentários. Tese. 2002. Universidade de São Paulo. Disponível em: http:// 
jforni.jor.br/forni/files/An\%C3\%A1lise\%20document\%C3\%A1 ria\%20de\%20fotografia s\%20-\%20 Miriam\%20Manini.pdf . Acesso em: 21 mar. 2020.

MELLO, B. A. A. Tradições discursivas do Exempla: da idade média aos folhetos de cordel. Revista do GELNE, Natal, RN, v.18, n.2, p.247-275, 2016.

MENEZES, F. C. Xilogravura: o sertão do nosso lugar. Trama interdisciplinar, [S.I.], v.1, n.1, 2010.

PATO, P. R. G.; MANINI, M. P. Polissemia da imagem, indexação e recuperação da informação. In: ENCONTRO NACIONAL DE PESQUISA EM CIÊNCIA DA INFORMAÇÃO, 14., Florianópolis, SC, 2013. Anais eletrônicos[...]. Florianópolis: ANCIB, 2013.

PANOFSKY, E. Meaning in the Visual Arts. London: Peregrine, 1977.

PANOFSKY. E. Significado nas Artes Visuais. Tradução M. C. F. Keese e J. Guinsburg. 3. ed. São Paulo: Perspectiva, 2007.

PAT0, P. R. G. Imagens: polissemia versus indexação e recuperação da informação. 2015. Tese (Doutorado em Ciência da Informação) - Faculdade de Ciência da Informação, Universidade de Brasília, Brasília, DF, 2015.

RODRIGUES, R. C. Análise e tematização da imagem fotográfica. Ciência da Informação, Rio de Janeiro, v.26, n.3, p.67-76, set./dez.2007. Disponível em: http://revista.ibict.br/ciinf/article/view/1167. Acesso em: 21 mar. 2020.

SANTOS, R. F. Indexação de xilogravuras em versos: a representação entre 0 real e 0 imaginário coletivo. 2019. Tese (Doutorado em Ciência da Informação) - Universidade Federal da Paraíba, João Pessoa, 2019.

SHATFORD, S. Analyzing the subject of a Picture: a theoretical approach. Cataloging \& Classification Quartely, [S.I.], v.6, n.3, p.39-62, 1986.

SMIT, J. W. A representação da imagem. Informare, Cadernos do Programa de Pós-Graduação em Ciência da Informação. Rio de Janeiro, v.2, n.2, p.28-36, jul./dez. 1996. 